\title{
Medijska pristranost? Izbori u Hrvatskoj 1990. u hrvatskom tisku
}

\author{
TOMISLAV KARDUM \\ Zagreb, Hrvatska \\ tkardum96@gmail.com
}

U radu se obrađuje praćenje predizborne kampanje prvih slobodnih izbora u Hrvatskoj u hrvatskom tisku. Autor je nastojao utvrditi je li postojala medijska pristranost u praćenju predizborne kampanje prvoga kruga parlamentarnih izbora 1990. u Hrvatskoj. Analizirano je na koji su način dnevnici (Vjesnik i Večernji list) i tjednici (Danas i $S T$ ) pisali o političkim strankama i koalicijama u promatranom razdoblju. Prvi cilj istraživanja bio je dokazati postoji li medijska pristranost, a drugi postoji li pluralizam medija nakon gotovo polustoljetnoga jednostranačkoga socijalističkog sustava. Pokazalo se da medijska pristranost postoji u svim promatranim medijima, ali se favorizirane i marginalizirane stranke razlikuju ovisno o promatranome mediju.

Ključne riječi: medijska pristranost; hrvatski izbori 1990.; tranzicija; medijski pluralizam; Hrvatska demokratska zajednica; Savez komunista Hrvatske - Stranka demokratskih promjena; Koalicija narodnog sporazuma

\section{Uvod}

Uloga medija na prvim slobodnim izborima u Hrvatskoj, i tranziciji općenito, slabo je istraživana. Način na koji su mediji pratili parlamentarne izbore 1990., izrazito važan događaj u demokratskim promjenama, bitan je kotačić u razumijevanju same tranzicije u Hrvatskoj, a time naravno i medijske tranzicije. Mediji su u predizbornoj kampanji komunikacijski kanal koji povezuje političare i javnost. ${ }^{1}$ Zbog toga su važni u predizbornoj kampanji, a pogotovo na prijelomnim izborima kao što su bili oni u Hrvatskoj 1990. godine. Mediji u takvim trenucima mogu odigrati bitnu ulogu jer javnost ne može u kratkom roku od pojave prvih stranaka do izbora biti upoznata s programom svih (brojnih) stranaka. Dakako, mediji selekcijom, naglašavanjem i vrijednosnim prikazom stranaka mogu utjecati na birače.

Predmet ovoga istraživanja način je na koji su hrvatski mediji pratili predizbornu kampanju za prvi krug parlamentarnih izbora 1990. u Hrvatskoj,

1 JAKUBOWICZ, „Television and Elections in Post-1989 Poland”, 131. 
održan 22. i 23. travnja 1990. godine. Točnije, glavna je tema način na koji su mediji prikazivali stranke i koalicije od početka predizborne kampanje 23. veljače pa do 21. travnja, kada je na snagu stupila predizborna šutnja. Pritom je istraženo pisanje dvaju tjednika (Danas i ST) i dvojih dnevnih novina (Vjesnik i Večernji list). ${ }^{2}$ Medijsko praćenje predizborne kampanje prvih slobodnih izbora u Hrvatskoj 1990. rijetko je bilo predmet znanstvenoga istraživanja. ${ }^{3}$ Međutim, nitko nije istraživao je li postojala medijska pristranost (media bias) u medijskom prikazu predizborne kampanje i stranaka/koalicija, što može biti važan aspekt proučavanja uloge novinstva u demokratskoj tranziciji i Domovinskom ratu. ${ }^{4}$

\section{Mediji i tranzicija u Hrvatskoj}

Preduvjet za prve slobodne izbore u Hrvatskoj bio je dakako početak tranzicije iz jednostranačkoga komunističkog sustava u demokratski poredak. Stvaranje demokratskih institucija, slobodni i demokratski izbori, omogućavanje slobode udruživanja i stvaranja političkih stranaka te sloboda medija temeljne su sastavnice demokratske tranzicije. ${ }^{5}$

Tranzicija započinje slabljenjem represivnosti režima, odnosno liberalizacijom, koja ne vodi nužno u stvaranje demokracije, a ako na vlast dođe demokratski izabrana opcija, nastupa proces konsolidacije demokracije, koji može dugo potrajati. ${ }^{6}$ Postoje tri faze transformacije sustava. Najprije propada autoritarni režim, zatim dolazi do demokratizacije i naposljetku nastupa proces konsolidacije. Sama tranzicija završava donošenjem ustava te nastupa proces konsolidacije demokracije, koji je uspješan ako se učvrste demokratske institucije, a demokratski poredak postane „siguran”, pa se njegovo postojanje ne dovodi u pitanje. ${ }^{7}$

Cijeli socijalistički blok krajem 80 -ih proživljava krizu zbog gubitka političke legitimnosti i katastrofalnih gospodarskih rezultata, pogotovo u uspo-

\footnotetext{
2 Večernji list i Vjesnik odabrani su za analizu kao najtiražnije dnevne novine koje nisu (primarno) regionalnoga karaktera - za razliku od Slobodne Dalmacije, Novoga lista i Glasa Slavonije. Prodana naklada Večernjega lista u veljači 1989. iznosila je 212499 primjeraka, a Vjesnika 70664 primjerka. NOVAK, Hrvatsko novinarstvo u 20. stoljeću, 949. ST i Danas jedini su tadašnji tjednici primarno političkoga sadržaja - Start je izlazio dvaput mjesečno te uslijed relativno kratkog promatranog perioda nije prikladan za ovu analizu. Naklada Danasa 31. prosinca 1988. bila je 79 tisuća primjeraka. Podaci o nakladi ST-a ne postoje za 1990. nego samo za veljaču 1992., kada je taj tjednik prodavan u 157 tisuća primjeraka. NOVAK, „Novinstvo“, 208, 212.

3 Vidi: PAUKOVIĆ, „Predizborna kampanja u Hrvatskoj 1990.”; THOMPSON, Kovanje rata.

4 O tome vidi: THOMPSON, Kovanje rata; KOLSTØ, Media Discourse and the Yugoslav Conflicts.

BUDIMIR, Politička elita u Hrvatskoj 1990. - 2000., 52.

6 SOEBERG, „Hrvatska nakon 1989. godine”, 36.

7 BUDIMIR, Politička elita u Hrvatskoj 1990. - 2000., 55-58.
} 
redbi s kapitalističkim svijetom. Rušenju komunističkih režima pridonijelo je i to što je Mihail Gorbačov, vođa Sovjetskoga Saveza, 1989. i formalno ukinuo Brežnjevljevu doktrinu, prema kojoj je Sovjetski Savez reagirao na ugrožavanje socijalističkoga poretka unutar Varšavskoga pakta (primjerice Čehoslovačka 1968.). Huntington kao faktore demokratizacije krajem 80 -ih navodi opadanje legitimnosti režima, ekonomski razvoj i ekonomske krize, religijske promjene, novu politiku vanjskih aktera i demonstracijski učinak, koji se odnosi na fenomen da demokratizacija u jednoj zemlji potiče demokratizaciju u drugim nedemokratskim zemljama, stvarajući tako situaciju sličnu domino-efektu. ${ }^{8}$ Suočeni s opozicijom režimu i krizom legitimnosti, čelnici zemalja Varšavskoga pakta nisu mogli računati na sovjetsku pomoć. Štoviše, Gorbačov je nakon pobjede opozicijskoga poljskog pokreta Solidarnost u lipnju 1989. čestitao Tadeuszu Mazowieckom. ${ }^{9}$ Ipak, kako ističu Kotkin i Gross, opozicija nije srušila komunističke režime zato što jednostavno nije postojala kao snažan faktor, uz moguću iznimku Mađarske i pogotovo Poljske. ${ }^{10}$

Slom komunizma u Europi imao je velik utjecaj na donošenje odluke o višestranačju u Hrvatskoj u prosincu 1989. godine. Prije njezina donošenja pao je Berlinski zid (studeni 1989.), a za vrijeme održavanja kongresa na kojem je donesena ta povijesna odluka urušavao se komunizam u Čehoslovačkoj uslijed Baršunaste revolucije. ${ }^{11} \mathrm{Na}$ 11. kongresu Saveza komunista Hrvatske, koji je trajao od 11. do 13. prosinca, konačno je poražena dogmatska struja Partije, a za predsjednika Centralnoga komiteta Saveza komunista Hrvatske izabran je Ivica Račan, porazivši pritom „konzervativnijega” Ivu Družića sa 41 naprema 29 glasova. ${ }^{12}$ Pauković kao razloge prihvaćanja višestranačja navodi unutarstranački faktor, koji se odnosi na borbu reformatora i dogmata, republički faktor, federalni faktor, odnosno velikosrpski „izvoz” antibirokratske revolucije i pokušaj organiziranja „mitinga istine” u Ljubljani, te međunarodni faktor, što se odnosi na slom komunizma. U Partiji je većina članova bila srednjostrujaška te je podržavala reformiste/dogmate u skladu s razvojem situacije, a navedeni su faktori išli u prilog reformistima. ${ }^{13}$ Opisani procesi pokazuju da je, kako kaže Budimir, do promjene došlo „odozgo”, odnosno „stvaranjem uvjeta od strane vladajuće komunističke elite po tzv. upravljanom obrascu". ${ }^{4}$

Tisak i mediji koji prate politiku „esencijalni” su za demokraciju da bi omogućili biračima donošenje informirane odluke. ${ }^{15}$ Zbog toga su sloboda

8 HUNTINGTON, Treći talas, 44-88.

9 KOTKIN, GROSS, Necivilno društvo, 9-13.

10 Isto, 10.

11 PAUKOVIĆ, Usred oluje, 176.

12 Isto, 124.

13 Isto, 125-126.

14 BUDIMIR, Politička elita u Hrvatskoj 1986. - 1990., 9.

15 SNYDER, STRÖMBERG, „Press Coverage and Political Accountability”, 355-356; PERUŠKO, „Mediji i civilne vrijednosti”, 193. 
medija i demokracija „usko povezani koncepti”. ${ }^{16}$ Kvalitetno pružanje informacija pogotovo je bitno u tranziciji jer je potrebno upoznati građane s novim institucijama, demokratskim procedurama, kandidatima, programima i sl. ${ }^{17}$ Loveless je pokazao da su građani „ovisni” o medijima u tranzicijskim zemljama jer su im potrebni da bi bili informirani o novim, nepoznatim procesima te ih u tu svrhu i koriste. Na taj način mediji provode političku socijalizaciju, a s druge strane u stabilnim društvenim sustavima građani ne moraju „tražiti” informacije o već ustaljenim i prihvaćenim obrascima. U skladu s tim, može se reći da su slobodni mediji preduvjet funkcionalne demokracije. ${ }^{18}$

Neovisni mediji koji nisu pod partijskom/državnom kontrolom podrazumijevaju medije kao autonomnoga aktera u suodnosu s drugim interesnim skupinama, centrima moći itd. U tom slučaju mediji imaju vlastitu agendu. ${ }^{19}$ Međutim, postavlja se pitanje jesu li mediji 1990. mogli biti neovisni nakon 45 godina partijske kontrole, $\mathrm{i}$ to formalne. Naime, u Jugoslaviji su rad medija kontrolirali republički i pokrajinski partijski komiteti, a tek 1989. donesen je savezni zakon kojim je omogućeno osnivanje privatnih medija. ${ }^{20}$ Prvi privatni medij u Hrvatskoj, ST (Slobodni tjednik), izaći će prvi put tek 28. veljače 1990. godine. ${ }^{21}$ Vladajuće komunističke partije $\mathrm{u}$ istočnom bloku koncentrirale su svu vlast u jednom centru, monopolizirajući ekonomsku, političku, društvenu i ideološku moć te poništavajući trodiobu vlasti. U takvu sustavu mediji nikako nisu mogli imati neovisnu ulogu. ${ }^{22}$ Stvoren je centralizirani medijski sustav, a država je imala ovlasti zabrane nepoćudnih medija, cenzure (uz raširenu autocenzuru), zabrane distribucije stranih publikacija itd. Mediji su kao državni aparat trebali postići „ideološku homogenizaciju publike i reprodukciju postojećega društvenog poretka”. ${ }^{23}$

U Jugoslaviji je država bila vlasnik izdavačkih poduzeća i tiskara. Najveća izdavačka kuća bilo je Novinsko-izdavačko i štamparsko poduzeće Vjesnik, $\mathrm{u}$ kojem su bili koncentrirani brojni mediji. ${ }^{24}$ Glavne dnevne novine osnivao je Socijalistički savez radnog naroda (SSRN), pa su republičke organizacije SSRN-a imenovale direktore, glavne i odgovorne urednike dnevnih novina, u hrvatskom slučaju Vjesnika i Večernjega lista. Općinske vlasti osnivale su regionalne i lokalne listove, pri čemu je Savez komunista imao ključan utjecaj. Časopisi su pak bili dio novinskih poduzeća ili organizacija unutar SSRN-a. Socijalistički savez nije samo osnivao novine, nego je morao dati dozvolu za njihovo osnivanje, a Savez komunista kontrolirao je sadržaj preko izdavač-

16 SMAELE, „In the Name of Democracy”, 45.

17 VOLTMER, „The Mass Media and the Dynamics of Political Communication”, 3.

18 LOVELESS, „Media Dependency”, 162-163.

19 MANCINI, SWANSON, „Television, Campaigning, and Elections in the Soviet Union and Post-Soviet Russia”, 11.

20 THOMPSON, Kovanje rata, 5.

21 NOVAK, Hrvatsko novinarstvo u 20. stoljeću, 964.

22 JAKUBOWICZ, „Media Within and Without the State”, 125.

23 Isto, 127

24 MIHALJEVIĆ, „Liberalizacija i razvoj medija u komunističkoj Hrvatskoj”, 241-242. 
kih savjeta. Usto su postojale i druge (pseudo)cenzorske institucije povezane s Centralnim komitetom Saveza komunista, poput Komisije za ideološki rad i Komisije za političku propagandnu aktivnost u informiranju. ${ }^{25}$ Ipak, u 80 -ima postoji mnogo veći pluralizam medija nego u prethodnim razdobljima. Primjerice, tjednik Danas, osnovan 23. veljače 1982., kritizira Miloševićevu politiku te prvi objavljuje priloge disidenata krajem 80 -ih. ${ }^{26}$

Važan aspekt medijske tranzicije je „redefinicija novinarstva”, odnosno promjena od shvaćanja novinara kao društveno-političkoga radnika prema autonomnome novinaru koji obavlja posao u javnom interesu i djeluje kao „četvrta vlast”. Pritom se postavlja pitanje mogu li u kratkom vremenu isti ljudi redefinirati svoju ulogu, što svakako može imati implikacije na praćenje predizborne kampanje 1990. godine. ${ }^{27}$

U skladu s navedenom podjelom na tri faze transformacije sustava, $P$. Gross izdvaja tri faze medijske tranzicije. Prvu fazu naziva „pripremnom” te kaže da počinje 1989. slomom komunističkih režima, a u nekim zemljama i prije zbog razvijene mreže podzemnih i alternativnih medija. Druga faza nastupa unutar uspostavljenoga demokratskog poretka, koji prvotno radi promjene koje se tiču zakonske regulacije medijske djelatnosti, a treća se događa u konsolidacijskoj fazi demokracije. ${ }^{28}$

Za vrijeme predizborne kampanje za izbore 1990. u Hrvatskoj komunistički je režim još uvijek bio na vlasti, a tek tijekom nje počele su određene promjene kojima je jasnije definiran status nekih novina. Tako je Društvo novinara i nakon početka izborne kampanje bilo član Socijalističkoga saveza radnog naroda Hrvatske (SSRNH), iako se ta organizacija transformirala u političku stranku Savez socijalista - Socijalistički savez Hrvatske. ${ }^{29}$ SSRNH je tek 10. ožujka 1990. prestao biti vlasnik Vjesnika. ${ }^{30}$ Savjet lista i skupština Vjesnika raspušteni su, a „preporučeno” je svim urednicima da ne budu članovi izvršnih organa političkih stranaka. Ipak, osnovna organizacija Saveza komunista redakcije Vjesnika raspuštena je tek 27. ožujka 1990. godine. ${ }^{31}$ Večernji list izdvojen je krajem 1989. iz Novinsko-izdavačke, štamparske i prodajne radne organizacije Vjesnik te je registriran kao društveno poduzeće. Od tada Socijalistički savez Hrvatske nije njegov izdavač te je ukinut Savjet Večernjega lista. ${ }^{32}$ Večernji list je također raspustio osnovnu organizaciju Saveza komunista u redakciji te je odlučeno da novinari, urednici i zaposlenici ne smiju

25 THOMPSON, Kovanje rata, 12.

26 NOVAK, Hrvatsko novinarstvo u 20. stoljeću, 801-805. Valja napomenuti da u Danasu priloge objavljuju osobe prilično različitih ideoloških profila. Primjerice, suradnik je budući savjetnik predsjednika Franje Tuđmana Slaven Letica, a tekstove objavljuje i Miroslav Lazanski, apologet tadašnjega sustava blisko povezan s Jugoslavenskom narodnom armijom.

27 JAKUBOWICZ, „Media Within and Without the State”, 136.

28 GROSS, „Between Reality and Dream”, 111.

29 F. VONDRAČEK, „Novinarski sindikat”, Vjesnik (Zagreb), 28. 2. 1990., 1.

30 Vjesnik, 10. 3. 1990., 1.

31 Vjesnik, 28. 3. 1990., 7.

32 Večernji list (Zagreb), 3. 3. 1990., 3. 
biti članovi izvršnih, političkih tijela u političkim strankama. ${ }^{33}$ Prigovore na medijsku pristranost, odnosno na nastavak sprege vlasti i medija opozicija je u kampanji često upućivala. Pritom je najčešće na meti kritika bila Televizija Zagreb. Primjerice, Franjo Tuđman istaknuo je da „uvjeti za borbu nisu podjednaki” jer „Savez komunista i Socijalistički savez raspolažu ne samo s jakim aparatom, nego još uvijek i s medijima”. ${ }^{44}$ Slično je u intervjuu ustvrdio Ante Miko Tripalo, jedan od čelnika Koalicije narodnog sporazuma (KNS), koji je rekao da Savez komunista ima utjecaj na „propagandu” i „sredstva informiranja" ${ }^{35}$

Pojedini novinari i komentatori sudjelovali su u političkoj kampanji. Tako su se primjerice na listi uglednika ${ }^{36}$ koji su javno podržali Savez komunista Hrvatske - Stranku demokratskih promjena (SKH-SDP) nalazili kolumnistica tjednika Danas Jelena Lovrić, književnica Slavenka Drakulić i književni kritičar Velimir Visković, koji su povremeno objavljivali priloge u Danasu, te profesorica s Fakulteta političkih nauka Mirjana Kasapović, autorica teksta objavljenog u Večernjem listu u kojemu se kritički progovara o Hrvatskoj demokratskoj zajednici (HDZ). ${ }^{37}$ Visković i Lovrić, koja je bila kandidatkinja ${ }^{38}$ SKH-SDP-a za Društveno-političko vijeće Sabora, govorili su na predizbornom skupu SKH-SDP-a u Domu sportova. ${ }^{39}$ Nadalje, novinar Danasa Gojko Marinković bio je kandidat Evropske zelene liste. ${ }^{40}$ Koalicija narodnog sporazuma svakodnevno je pak izdavala bilten u 200 primjeraka za novinare, za što je bila zadužena tvrtka Media press. Vlasnici Media pressa bili su novinari Danasa Ratko Bošković i Rene Bakalović te novinar Starta Denis Kuljiš, ali oni nisu bili članovi KNS-a. ${ }^{41}$ Ipak, valja istaknuti da su mediji poput Večernjega lista i Vjesnika učinili neke korake da bi osigurali ravnopravan pristup medijima, barem u određenoj sferi. Tako je Večernji list dogovorio sa strankama da će stranački programi biti predstavljeni na istom prostoru, veličine oko pola stranice svakoga dana, a redoslijed je određen ždrijebanjem. ${ }^{42}$ Vjesnik je pak od 27. veljače iz broja u broj objavljivao feljtone kojima su predstavljeni programi svih sudionika izbora.

33 Isto.

34 J. SINKOVIĆ, „Dr Franjo Tuđman: imamo najhrvatskiji program”, Vjesnik, 25. 2. 1990., 10.

35 M. MALOČA, „Iskušenja novog izleta”, ST (Split), 13. 3. 1990., 11.

36 PAUKOVIĆ, Usred oluje, 153.

37 M. KASAPOVIĆ, „Tuđmanizacija Hrvatske”, Večernji list, 10. 3. 1990., 5.

38 BUDIMIR, Politička elita u Hrvatskoj 1986. - 1990., 305.

39 Z. DASKALOVIĆ, N. KRALJEVIĆ, M. PLEŠE, „Sačuvati dobro, iskorijeniti zlo”, Vjesnik, 1. 4. 1990., 1.

40 Ž. BUKŠA, D. PAVIČIĆ, „Kakva politika takav hakl”, Vjesnik, 17. 4. 1990., 12.

41 Ž. BUKŠA, „Groznica predizborne večeri”, Vjesnik, 19. 4. 1990., 3.

42 Z. DUKA, „Potpuno ravnopravan tretman”, Večernji list, 2. 3. 1990., 5. 


\section{Medijska pristranost}

Novinari nužno moraju biti selektivni i uspostaviti prioritet jer je prostor u novinama posvećen praćenju kampanje ograničen, zbog čega ne mogu sve opcije biti jednako predstavljene..$^{43}$ Mediji nisu neutralni, tj. nisu posrednik između glasača i političara. Oni aktivno sudjeluju prezentiranjem događaja i političkih poruka te naravno samim određivanjem toga što je vrijedno da dobije medijski prostor. ${ }^{44} \mathrm{McQuail}$ definira pristranost kao „svaku tendenciju devijacije od točne, neutralne, balansirane i nepristrane reprezentacije stvarnosti događaja te društvenih događaja u vijestima". ${ }^{45}$ Entman upozorava na to da je potrebno napraviti distinkciju između pristranosti (bias) i sklonosti $($ slant $) .^{46}$ Pritom se potonji pojam odnosi na „pojedinačne vijesti i uredničke priloge u kojima uokvirivanje (framing) favorizira jednu stranu u odnosu na drugu u postojećem ili potencijalnom sporu" ${ }^{47} \mathrm{Za}$ nas ključan pojam medijske pristranosti odnosi se na postojanje „obrazaca sklonosti (slant) koji redovito potiču publiku, svjesno ili nesvjesno, da podrži interese partikularnih nositelja političke moći ili onih koji traže političku moć" ${ }^{48}$ Sličnu definiciju daje i Groeling, za kojega je medijska pristranost „prikaz stvarnosti koji je značajno i sustavno (ne slučajno) iskrivljen [kurziv dodan]". ${ }^{49}$ Bitno je istaknuti da „prikaz stvarnosti” ne podrazumijeva jednak pristup za sve opcije na izborima jer nisu sve opcije jednako relevantne, o čemu će poslije biti riječi.

Uokvirivanje (framing) i postavljanje agende također mogu biti dio objašnjenja za postojanje medijske pristranosti. Uokvirivanje se može definirati kao način interpretiranja pojedinačnih činjenica u određenom okviru. Takva su pojednostavnjivanja neophodna za novinare, a sama po sebi predstavljaju određenu vrstu pristranosti..$^{50}$ Za Kunczika i Zipfel frame je „interpretacijski okvir”, tj. riječ je o „kognitivnim strukturama u svijesti novinara koje olakšavaju selekciju i obradu informacija". ${ }^{51}$ Postavljanje agende odnosi se na određivanje koji su događaji i fenomeni „vrijedni” medijske pozornosti, a koji nisu. ${ }^{52}$ Ukratko, mediji nisu preslika stvarnosti nego konstrukcija stvarnosti. ${ }^{53}$ Mediji samim odabirom tema „postavljaju agendu” budući da medijski sadržaji nikada nisu odraz stvarnosti, a teme koje su prioritet za medije ne moraju biti prioritetne medijskim konzumentima. ${ }^{54}$ Tri velika utjecaja na medijsku

\footnotetext{
43 VAN DALEN, „Structural Bias in Cross-National Perspective”, 34.

44 VOLTMER, „The Mass Media and the Dynamics of Political Communication”, 7.

45 MCQUAIL, McQuail's Mass Communication Theory, 549.

46 ENTMAN, „Framing Bias”, 165-166.

Isto, 165.

Isto, 166.

GROELING, „Media Bias by the Numbers”, 133.

MCQUAIL, McQuail's Mass Communication Theory, 380.

51 KUNCZIK, ZIPFEL, Uvod u znanost o medijima i komunikologiju, 147-148.

52 ENTMAN, „Framing Bias”, 164-165.

53 RIFFE, LACY, FICO, Analyzing Media Messages, 9.

54 KUNCZIK, ZIPFEL, Uvod u znanost o medijima i komunikologiju, 197-198.
} 
agendu su: utjecajni izvori (pogotovo institucionalni), drugi mediji (intermedia agenda setting) i „društvene norme i novinarska tradicija”. ${ }^{55}$ Ti utjecaji na medijsku agendu lako proizvode tzv. nesvjesnu/nenamjernu pristranost (unwitting bias), koja nije rezultat namjernoga favoriziranja određene stranke, nego proizlazi iz spomenutih čimbenika. ${ }^{56}$

D’Alessio i Allen razlikuju tri vrste medijske pristranosti. Prva se odnosi na izostavljanje i potpuno marginaliziranje stranaka koje se percipiraju beznačajnima, što nazivamo tzv. vratarskom pristranošću (gatekeeping bias). Druga se vrsta odnosi na pristranost u prikazivanju, odnosno na neravnomjeran prostor koji se daje relevantnim strankama (coverage bias). Treća se pak pristranost odnosi na vrijednosne sudove, odnosno pristranost medijskih stavova (statement bias). Dakle, odnosi se na više pozitivan ili negativan prikaz relevantne opcije u odnosu na drugu relevantnu opciju. ${ }^{57}$ Groeling govori o „stranačkoj pristranosti” (partisan bias), koju definira kao „Znatno iskrivljen prikaz stvarnosti koji sustavno i disproporcionalno favorizira jednu stranku u odnosu na drugu". 58

Entman također razlikuje tri vrste pristranosti. Prva je distorzijska pristranost (distorsion bias), koja se odnosi na sadržaje koji „falsificiraju realnost”. Druga je sadržajna pristranost (content bias), koja se odnosi na nejednak prostor dan različitim opcijama, što je ekvivalent pristranosti u izvještavanju. Treća se odnosi na namjernu pristranost (decision-making bias), koja je plod novinarove odluke, odnosno njegova subjektivnoga stava spram teme, stranke ili opcije, zbog kojega će o određenim strankama iznositi pozitivne/negativne vrijednosne sudove. ${ }^{59}$ Posljednja vrsta medijske pristranosti također je slična podjeli koju navode D’Alessio i Allen. U radu će se istražiti postoje li navedene pristranosti, osim distorzijske. Važno je istaknuti da su druga i treća pristranost po D’Alessiju i Allenu vrlo slične Entmanovoj podjeli. Testiranje postojanja distorzijske pristranosti odbacuje i sam Entman. ${ }^{60}$ Takvu vrstu pristranosti teško možemo utvrditi te bi istraživanje poprimilo subjektivni karakter. Postojanje „vratarske” pristranosti lako možemo potvrditi ako je frekvencija pojavljivanja manjih stranaka statistički zanemariva.

Međutim, budući da se radi o prvim izborima, postavlja se pitanje kako odrediti koje su stranke relevantne, a koje marginalne. Možemo se poslužiti jedino istraživanjima javnoga mišljenja koja pružaju okvirnu sliku o relevantnosti stranaka. Anketa Večernjega lista provedena 12. - 14. ožujka, u kojoj je sudjelovalo 470 ispitanika, pokazala je da se $18,5 \%$ ispitanika odlučilo za SKH-SDP, 15,6 \% za HDZ, 13,7 \% za KNS i 6 \% za Evropsku zelenu listu. ${ }^{61}$

\footnotetext{
55 WEAVER, MCCOMBS, SHAW, „Agenda-Setting Research”, 269.

56 MCQUAIL, McQuail's Mass Communication Theory, 521.

57 D’ALESSIO, ALLEN, „Media Bias in Presidential Elections”.

58 GROELING, „Media Bias by the Numbers”, 133.

59 ENTMAN, „Framing Bias”, 163.

60 Isto

61 PAUKOVIĆ, Usred oluje, 176.
} 
Iako se „Zeleni” u raznim oblicima pojavljuju u anketama i prije formiranja koalicije, a po nekim anketama iz 1989. bili su i najsnažnija opcija, bilo je jasno da su na izborima tri ključne opcije HDZ, SKH-SDP i KNS.

Prema Sartoriju, manje su stranke relevantne ako imaju koalicijski potencijal za ulazak u vladu ili „ucjenjivački” potencijal, što znači da svojom relevantnošću utječu na druge aktere, ali nemaju koalicijski potencijal, poput primjerice često druge po snazi Talijanske komunističke partije. Dakle, stranke koje ne mogu utjecati na možebitno formiranje vlade suvišne su. ${ }^{62}$ Postoji stanoviti začarani krug jer relevantne stranke utječu na medijsku agendu „produkcijom” događaja, pa, kako zaključuju Hopmann i suradnici, „ako si relevantan, imaš utjecaj, a zato što imaš utjecaj, relevantan si". ${ }^{63}$ Večernji list istaknuo je 18. travnja u redakcijskom tekstu kojim se reflektira na praćenje kampanje: „[...] primijećeno je da su informativno u Večernjem listu bile najzastupljenije vodeće stranke i koalicije (HDZ, SKH-SDP i KNS), ali to je uvjetovalo njihovo znatno učestalije javno angažiranje i pojavljivanje od ostalih stranaka [kurziv dodan]. ${ }^{\prime 64}$ Posljednji dio citata stoji jer političke stranke utječu na medijski sadržaj u kampanji raznim aktivnostima, pseudodogađajima i sl. ${ }^{65}$ Međutim, to je na neki način također znak relevantnosti, ali za veliku diskrepanciju u frekvenciji pojavljivanja u medijskim sadržajima ne može biti „okrivljena” samo stranačka „proizvodnja” događaja.

Argument u prilog tome da su ostale stranke marginalne jest i broj kandidata za 80 mjesta u Društveno-političkom vijeću. Naime, natjecalo se 382 kandidata, od kojih je bilo 78 HDZ-ovih, 75 KNS-ovih, 73 iz SKH-SDP-a, 60 kandidata stranke Socijalistički savez - Savez socijalista Hrvatske (SS-SSH) te 12 zajedničkih kandidata SKH-SDP-a i SS-SSH-a. Evropska zelena lista ${ }^{66}$ kandidirala je samo 8 kandidata, odnosno izašli su na izbore u 8 od 80 izbornih jedinica, a sve ostale stranke zajedno kandidirale su 30 kandidata, a bilo je i 46 nezavisnih kandidata. ${ }^{67}$ Poštujući argument o relevantnosti stranke u skladu s brojem kandidiranih kandidata, proizlazi da je i SS-SSH relevantna opcija kojoj bi svakako trebao biti posvećen najveći prostor nakon HDZ-a, SKH-SDP-a i KNS-a. Zbog velikoga broja kandidata SS-SSH svakako je imao koalicijski potencijal, iako se znalo da ne može biti izborni pobjednik. U skladu s navedenim, smatrat će se da „vratarska” pristranost postoji ako su ostale stranke zanemarivo predstavljane u promatranim medijima.

Političari za koje se smatra da potencijalno mogu imati moć ili trenutačno imaju političku moć dobivaju više prostora od manje važnih aktera. ${ }^{68}$ Također,

\footnotetext{
62 SARTORI, Parties and Party Systems.

63 HOPMANN et al., „Party Media Agenda-Setting”, 186.

64 Večernji list, 18. 4. 1990., 5.

65 HOPMANN et al., „Party Media Agenda-Setting”.

${ }^{66}$ U tabličnom prikazu zbog jednostavnijega prikaza i snalaženja bit će navedena kao Zeleni.

67 PAUKOVIĆ, Usred oluje, 177.

68 VAN DALEN, „Structural Bias in Cross-National Perspective”, 34.
} 
snažni akteri većinom ulažu više sredstava u vođenje kampanje, imaju lakši pristup novinarima, što uz veću vrijednost vijesti (newsworthiness) u kojima sudjeluju snažni akteri stvara učinak „kumulativne nejednakosti” spram onih koje se percipira autsajderima, koji teže dobivaju prostor u medijima. ${ }^{69}$

Uz pitanje utvrđivanja sadržajne pristranosti ili pristranosti u izvještavanju (u nastavku će se koristiti izraz sadržajna pristranost) također se postavlja pitanje kako postaviti kriterije za postojanje medijske pristranosti. U dvostranačkim sustavima, poput američkoga, situacija je jasna jer postoje dvije najveće stranke, pa se smatra da pristranost ne postoji kada je otprilike podjednak prostor dan republikancima i demokratima. ${ }^{70}$ Budući da je riječ o prvim izborima, nepristrano praćenje izbora značilo bi podjednak prostor posvećen HDZ-u, SKH-SDP-u i KNS-u jer se nije moglo sa sigurnošću pretpostaviti koja je stranka najsnažnija. Postojanje pristranosti medijskih stavova lako se utvrđuje udjelom pozitivnih, negativnih, neutralnih i mješovitih prikaza stranke/koalicije u objavi. Pritom je, naravno, važno je li vrijednosni prikaz stranke rezultat izvora vijesti ili stava koji izriče novinar.

Nepristrana bi vijest trebala sadržavati različite izvore i prikazivati različita gledišta. Također bi činjenice trebale biti odvojene od mišljenja te ne bi trebalo biti vrijednosnih sudova. ${ }^{71}$ Groseclose i Milyo upravo su kvantifikacijom izvora utvrdili postojanje medijske pristranosti. Oni su istražili koliko puta određeni medij citira liberalne/konzervativne think-thankove te su ustanovili da od 20 promatranih američkih medija 18 ima liberalnu pristranost, a samo Fox News Special Report i Washington Times imaju konzervativnu pristranost. ${ }^{72} \mathrm{Wu}$, Sylvester i Hamilton istraživali su način na koji novine Philadelphia Inquirer prikazuju izraelsko-palestinski sukob. Ustanovili su da su palestinska i izraelska strana podjednako često prikazivane pozitivno, neutralno, negativno i mješovito, iz čega su zaključili da ne postoji medijska pristranost. Takav će kriterij biti primijenjen i u ovom radu. ${ }^{73}$ Primjerice, ako je HDZ prikazan negativno u 35 \% objava, KNS u 33 \% objava, a SKH-SDP u samo $12 \%$ objava, tada je jasno da postoji medijska pristranost u korist SKH-SDP-a.

Slijedom svega navedenog možemo zaključiti da se temeljna hipoteza o postojanju medijske pristranosti temelji na: a) strukturnim razlozima koji se odnose na organizacijsku logiku medija, društvene norme itd.; b) tradiciji jednostranačja i potencijalnoj nespremnosti medija za pružanje jednakih uvjeta svim opcijama; c) povijesnom značenju prvih slobodnih izbora, zbog čega se može pretpostaviti da će mediji imati aktivniju ulogu.

69 Isto, 35.

70 D’ALESSIO, ALLEN, „Media Bias in Presidential Elections”, 137-138.

71 MCQUAIL, McQuail's Mass Communication Theory, 356-357.

72 GROSECLOSE, MILYO, „A Measure of Media Bias”.

73 WU, SYLVESTER, HAMILTON, „Newspaper Provides Balance in Palestinian/Israeli Reports". 


\section{Stranke i koalicije na izborima}

Prema Zakonu o izboru i opozivu odbornika i zastupnika od 15. veljače 1990. uveden je dvokružni većinski izborni sustav za prve izbore nakon 45-godišnjega jednostranačja. Ako u prvom krugu izbora nijedan kandidat ne bi dobio više od $50 \%$ glasova u određenoj izbornoj jedinici, drugi krug izbora održao bi se za 14 dana. U drugom su krugu mogli sudjelovati kandidati koji dobiju najmanje 7 \% glasova, a mandat bi osvojio kandidat s najvećim brojem glasova. ${ }^{74}$ Zakonodavna vlast u Socijalističkoj Republici Hrvatskoj bila je trodomna. Sastojala se od Vijeća općina, Društveno-političkoga vijeća i Vijeća udruženog rada. Za Društveno-političko vijeće glasali su svi građani po izbornim jedinicama, za Vijeće udruženog rada samo zaposleni građani, a za Vijeće općina svaka općina, neovisno o broju stanovnika, davala je po jednoga zastupnika. ${ }^{75}$

U Hrvatskoj su do početka izbora registrirane 33 stranke. ${ }^{76}$ Dobar dio njih bio je organiziran u koalicije. Hrvatska demokratska zajednica osnovala je 5. travnja Hrvatski demokratski blok s nekoliko manjih stranaka. Članice $\mathrm{Hr}$ vatskoga demokratskog bloka, uz HDZ, bile su Hrvatska stranka (HS), koju su osnovali Hrvoje Šošić i Ante Korljan nakon isključenja iz Hrvatske kršćanske demokratske stranke (HKDS), zatim Hrvatska stranka prava (HSP), koja nije istaknula svoje kandidate na izborima, Demokratska kršćanska stranka (DKS), Demokratska akcija Hrvatske (DAH) i frakcija Hrvatske seljačke stranke (HSS) Ivana Zvonimira Čička. Stranke su samostalno izlazile na izbore, a dogovor je bio da u drugom krugu podrže kandidate bloka koji dobiju najviše glasova. ${ }^{77}$ Budući da je ta koalicija formirana vrlo kasno te da je HDZ bio mnogo snažniji od svih drugih stranaka Hrvatskoga demokratskog bloka, one će $\mathrm{u}$ analizi građe biti promatrane odvojeno od HDZ-a do 5. travnja, a nakon osnutka koalicije zajedno s HDZ-om. Savez komunista je 20. ožujka u naziv stranke dodao dio Stranka demokratskih promjena, pa je stranka nastupila na izborima pod imenom SKH-SDP. Socijalistički savez radnog naroda 7. veljače 1990. promijenio je ime u Socijalistički savez - Savez socijalista Hrvatske, a predsjednik im je bio Željko Mažar. ${ }^{78}$ Iako su u kampanji SS-SSH i SKH-SDP sudjelovali pretežito odvojeno, „obje su stranke zapravo nastupale kao jedinstveni izborni blok (svojevrsna koalicija vladajućih političkih snaga), o čemu svjedoče zajednički kandidati u nizu izbornih jedinica". ${ }^{79}$ Od ostalih društveno-političkih organizacija na izborima je sudjelovao i Savez sindikata Hrvatske te Savez socijalističke omladine Hrvatske (SSOH). Od SSOH odvojio se Autonomni demokratski savez Hrvatske (ADSH) na čelu s Darinkom

\footnotetext{
74 PODOLNJAK, „Hrvatsko izborno zakonodavstvo”, 336.

75 KASAPOVIĆ, „Strukturna i dinamička obilježja političkog prostora i izbori”, 43.

76 G, LITVAN, „Šaka novih demokrata”, Večernji list, 19. 4. 1990., 5.

77 D. IVANKOVIĆ, „Volja hrvatskog naroda”, Večernji list, 6. 4. 1990., 6.

78 BUDIMIR, Politička elita u Hrvatskoj 1990. - 2000., 104.

79 ZAKOŠEK, „Izborna geografija hrvatskih izbora 1990.”, 218.
} 
Kosorom, koji je na izbore izašao u sklopu koalicije zelenih stranaka, odnosno Evropske zelene liste (EZL) ${ }^{80}$ Budući da nije postojala formalna koalicija, društveno-političke organizacije bit će promatrane odvojeno od SKH-SDP-a.

Koalicija narodnog sporazuma službeno je osnovana 1. ožujka, a činili su ju Hrvatska socijalno-liberalna stranka (HSLS), Hrvatska demokratska stranka (HDS), Socijaldemokratska stranka Hrvatske (SDSH), Hrvatska kršćanska demokratska stranka i istaknute ličnosti Hrvatskoga proljeća kao nestranački kandidati (uz brojne druge nestranačke osobe): Savka Dabčević-Kučar, Ante Miko Tripalo, Ivan Supek, Dragutin Haramija i Srećko Bijelić. Poslije se koaliciji pridružio HSS, odnosno frakcija HSS-a Nikole Novakovića, Hrvatski mirotvorni pokret, Demokratski savez Albanaca Hrvatske i Muslimanska demokratska stranka ${ }^{81}$ Članice KNS-a u analizi neće biti promatrane odvojeno nego integralno.

Evropska zelena lista osnovana je 15. ožujka, a dio koalicije bili su: Autonomni demokratski savez Hrvatske, Radikalno udruženje za Sjedinjene Evropske države (RUSED), Zelena akcija Zagreb (ZAZ). Ubrzo su se Evropskoj zelenoj listi pridružile Zelena stranka Rijeke i izvanstranačka organizacija Ženska lista Medveščaka, a Zelena akcija Split (ZAS) samostalno je izašla na izbore. ${ }^{82}$ Članice Evropske zelene liste također neće u analizi biti navođene odvojeno, nego će se ta koalicija promatrati integralno.

Srpska demokratska stranka (SDS) Jovana Raškovića nastupala je sa srpskih nacionalističkih pozicija, zalažući se (tada) za mogućnost osnivanja autonomnih srpskih područja u Hrvatskoj, a Jugoslavenska samostalna demokratska stranka (JSDS) pozivala se na jugoslavensku tradiciju, bratstvo i jedinstvo itd., ali je okupljala gotovo isključivo srpsko stanovništvo. Na tom dijelu političkoga spektra postojala je i Stranka Jugoslavena. ${ }^{83}$ Socijaldemokratski savez Hrvatske (SDSH/J), kojemu je predsjednik bio Milorad Pupovac, nastao je iz krila Udruženja za jugoslavensku demokratsku inicijativu (UJDI) koje je htjelo izaći na izbore. ${ }^{84}$ Postojale su i regionalne stranke poput Istarskoga demokratskog sabora (IDS), Riječkoga demokratskog saveza (RDS), Stranke nezavisne demokracije (SND) i druge manje stranke poput Bosanske demokratske stranke (BDS), Građanske stranke (GS), Pokreta za konfederaciju itd. ${ }^{85}$

\footnotetext{
80 D. IVANKOVIĆ, „Nova koalicija”, Večernji list, 16. 3. 1990., 5.

81 PAUKOVIĆ, Usred oluje, 161-163. Budući da se o formiranju koalicije pisalo već na sam dan početka kampanje, 24. veljače, istupi sastavnica koalicije prije formiranja KNS-a bit će tretirani kao KNS. Dragan Đurić piše 24. veljače u Vjesniku da je najavljena koalicija demokršćana, socijaldemokrata, liberala i Hrvatske demokratske stranke, kojoj bi se kao nestranačke ličnosti pridružili Savka Dabčević-Kučar, Miko Tripalo, Dragutin Haramija i Srećko Bijelić. D. ĐURIĆ, „Utrka”, Vjesnik, 24. 2. 1990., 1.

82 D. IVANKOVIĆ, „Nova koalicija”, Večernji list, 16. 3. 1990., 5; Ž. BUKŠA, „Nuklearku pod ključ", Vjesnik, 31. 3. 1990., 4.

83 PAUKOVIĆ, Usred oluje, 168-169; ŠIBER, „Nacionalna, vrijednosna i ideologijska uvjetovanost stranačkog izbora", 128.

84 Z. DUKA, „Osnovan SDS Hrvatske”, Večernji list, 27. 2. 1990., 5.

85 PAUKOVIĆ, Usred oluje, 170.
} 


\section{Metodologija istraživanja}

Prvi cilj ovoga istraživanja jest ustanoviti postoji li medijska pristranost u praćenju predizborne kampanje u promatranim medijima, odnosno u pisanju o političkim strankama/koalicijama te, ako postoji, o kojim je vrstama medijske pristranosti riječ. Drugi je cilj ustanoviti postoje li razlike u obrascima praćenja predizborne kampanje u promatranim medijima. Drugi cilj istraživanja povezan je i s utvrđivanjem (ne)postojanja medijskoga pluralizma za vrijeme predizborne kampanje nakon dugogodišnje jednostranačke, režimske supresije medija promatranih kao alat vlasti. Naime, ako bi se ustanovilo da svi promatrani mediji na vrlo sličan način izvještavaju o predizbornoj kampanji, teško bismo mogli govoriti o medijskom pluralizmu. Postavljene su hipoteze koje adresiraju ciljeve istraživanja:

H1: U medijskom praćenju prvoga kruga parlamentarnih izbora 1990. postoji pristranost.

H2: Promatrani mediji marginalizirat će stranke za koje se pretpostavljalo da neće postići veći uspjeh, a golema većina članaka bit će posvećena izbornim „favoritima” - SKH-SDP-u, KNS-u i HDZ-u („vratarska” pristranost).

H3: Postoji sadržajna pristranost, ali se „privilegirane” stranke/koalicije razlikuju ovisno o mediju.

H4: Postoji pristranost medijskih stavova, ali se „privilegirane” stranke/ koalicije razlikuju ovisno o mediju.

Istraživačka metoda korištena u istraživanju je kvantitativna analiza sadržaja ${ }^{86}$ Uzorak istraživanja čine svi članci u promatranim medijima koji su povezani s predizbornom kampanjom za izbore 1990. godine. Analizom su prikupljeni članci koji imaju „predizbornu implikaciju”, dakle i oni kojima kampanja nije fokus, ali su predmet članka neki akteri predizborne kampanje. Riječ je o neprobabilističkom namjernom uzorku koji se koristi zbog „logičkih ili deduktivnih razloga koje nameće priroda istraživačkoga projekta". ${ }^{87}$ Primjerice, ako se u članku govori o ulozi Ante Mike Tripala u Hrvatskom proljeću, taj je članak analiziran jer se u njemu govori o jednom od ključnih aktera predizborne kampanje. Večernji list i Vjesnik izlazili su svakoga dana predizborne kampanje, pa analiziranu građu čine svi brojevi tih novina od 24. veljače do početka predizborne šutnje, stoga su posljednji analizirani brojevi izašli 20. travnja. Ukupno je dakle analizirano 56 brojeva Večernjega lista i 56 brojeva Vjesnika. Prvi broj tjednika Danas nakon početka predizborne kampanje izašao je 27. veljače, a posljednji broj prije početka izborne šutnje 17. travnja. Prvi broj $S T$-a izašao je 28 . veljače, a posljednji broj prije početka izborne šutnje 18. travnja. Ukupno je dakle analizirano 8 brojeva tjednika

${ }^{86}$ Više o kvantitativnoj analizi sadržaja vidi u: RIFFE, LACY, FICO, Analyzing Media Messages.

${ }^{87}$ Isto, 74 . 
Danas i 8 brojeva ST-a. Analiziranu građu ukupno čini 1185 članaka, od kojih 497 u Večernjem listu, 580 u Vjesniku, 71 u Danasu i 37 u ST-u.

\section{Rezultati istraživanja}

Pokazatelji medijske zastupljenosti su sljedeći: koliko je puta stranka zauzimala najveći prostor u članku, koliko je puta citirana izjava člana stranke/ koalicije ili same stranke/koalicije te u koliko se članaka govori o stranci. Pritom je važno napomenuti da se pod „strankom” misli i na članove stranke. Pokazatelji vrijednosnoga prikaza stranaka su pozitivan, negativan, neutralan ili mješovit prikaz stranke u članku. To su temeljne kategorije kojima će biti utvrđeno (ne)postojanje pristranosti u promatranim medijima. Zbog velike razlike u broju članaka ovisno o promatranom mediju rezultati će često biti iznošeni posebno. Citiranost stranke/koalicije u prilozima dobar je pokazatelj zastupljenosti pogleda te stranke u novinama. Naime, stranka može biti predmet članka i ako drugi govore o njoj ili ako ju se kritizira. Upravo izravnim iznošenjem svojih stavova stranka dopire do publike. Za razliku od frekvencije citiranosti stranke, iznošenje tvrdnji o stranci nije povezano s izravnim predstavljanjem stranke, tako da u diskrepanciji između tih dvaju rezultata možemo detektirati sadržajnu pristranost.

Grafikon 1. Objave u kojima je citirana stranka/koalicija ili član stranke/koalicije (Večernji list)

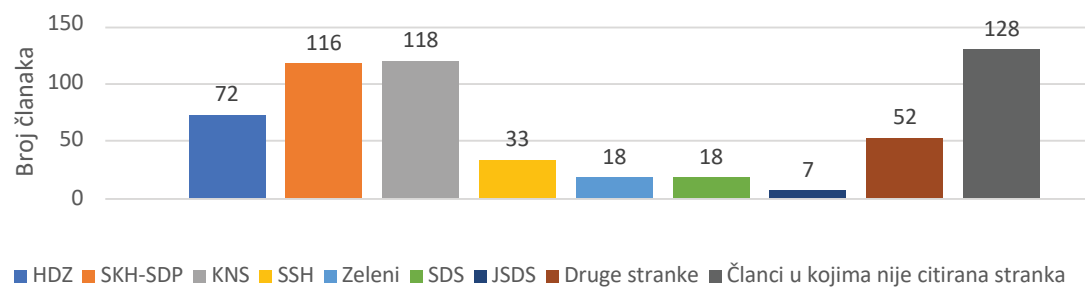

Grafikon 2. Objave u kojima se govori o stranci/koaliciji (Večernji list)

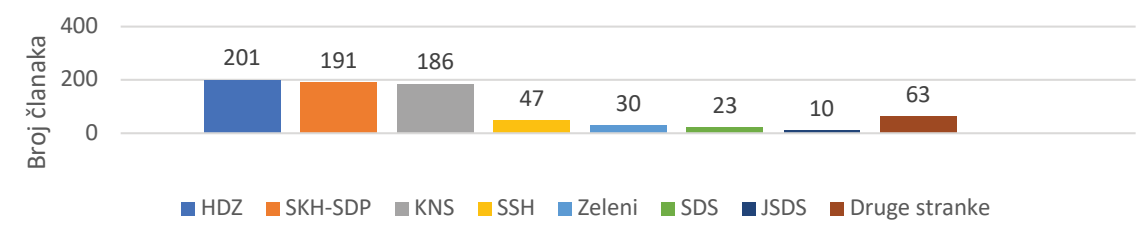


Kao što je vidljivo iz grafikona 2, HDZ je stranka o kojoj se u člancima najčešće govorilo u Večernjem listu, a marginalne stranke izrazito su podzastupljene. Možemo ustvrditi da u Večernjem listu postoji sadržajna pristranost jer HDZ-u nije posvećen prostor za predstavljanje stavova približno koliko drugim izbornim favoritima iako je HDZ stranka o kojoj se govorilo podjednako često kao i o druga dva favorita.

Grafikon 3. Objave u kojima je citirana stranka/koalicija ili član stranke/koalicije (Vjesnik)

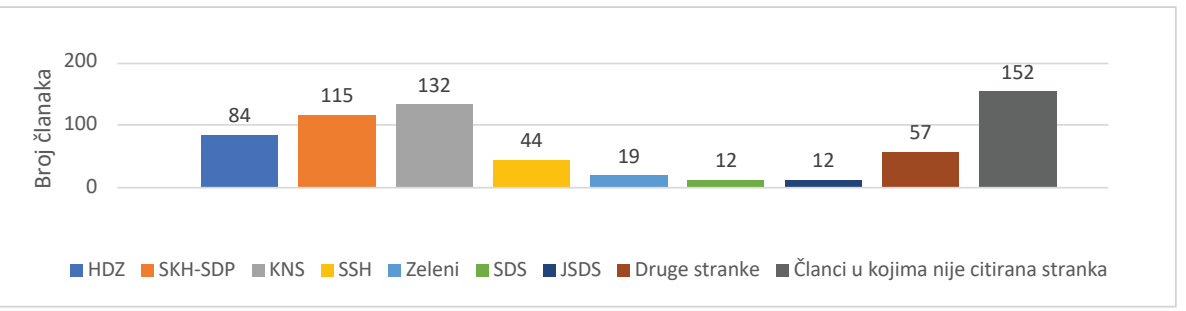

Grafikon 4. Objave u kojima se govori o stranci/koaliciji (Vjesnik)

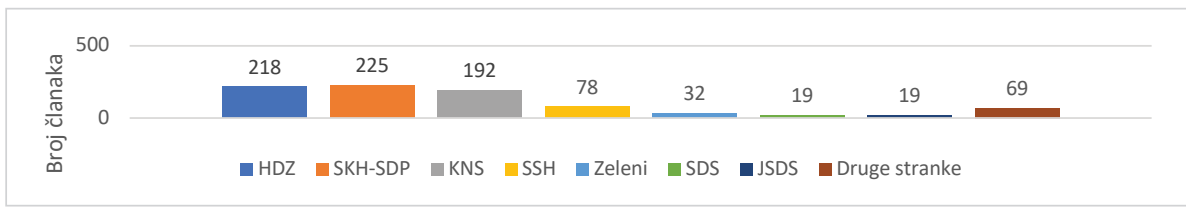

Vjesnik i Večernji list slijede slične obrasce u prikazu stranaka, s tom razlikom što Vjesnik daje veći prostor SSH-u. Tako je HDZ bio citiran u 47 članaka manje od KNS-a, a SSH u 41 članku manje od HDZ-a. Ta razlika pokazuje da postoji pristranost u prikazivanju ili sadržajna pristranost jer je citiranost HDZ-a znatno manja.

Grafikon 5. Prilozi u kojima je citirana stranka/koalicija ili član stranke/koalicije (Danas)

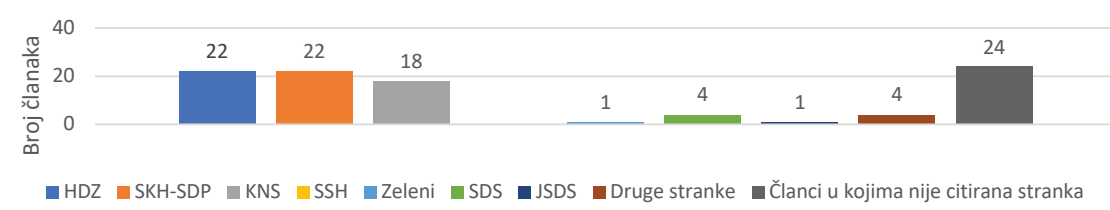


Grafikon 6. Prilozi u kojima se govori o stranci/koaliciji (Danas)

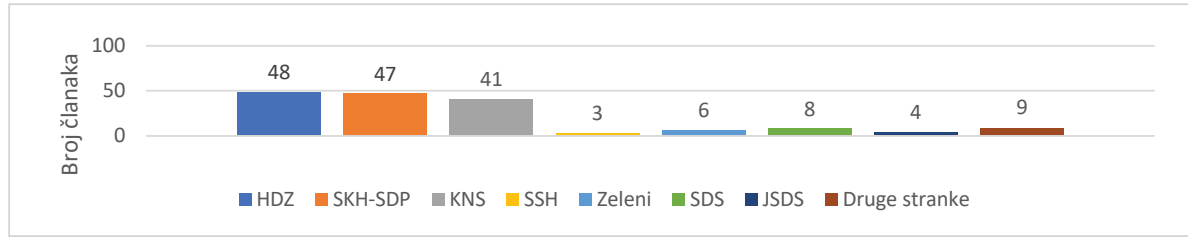

Danas pokazuje izraženiju „vratarsku” pristranost od dnevnih novina dodatnim marginaliziranjem svih stranaka/koalicija osim triju najjačih, dok četvrta stranka po snazi, SSH, nije čak nijednom citirana, a samo se u tri članka o njoj govorilo. S druge strane o KNS-u govorilo se u 10 članaka manje nego o HDZ-u. Međutim, veći broj članaka u kojima se govori o nekoj stranci ne mora nužno značiti „korist” za nju jer može biti riječ o pretežito negativno usmjerenim objavama.

Grafikon 7. Prilozi u kojima je citirana stranka/koalicija ili član stranke/koalicije $(S T)$

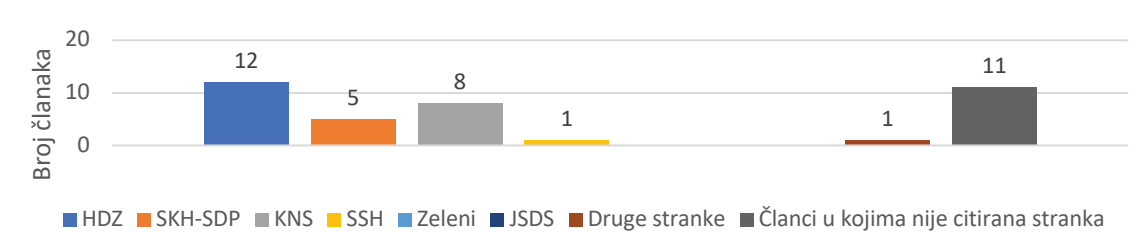

Grafikon 8. Prilozi u kojima se govori o stranci/koaliciji (ST)

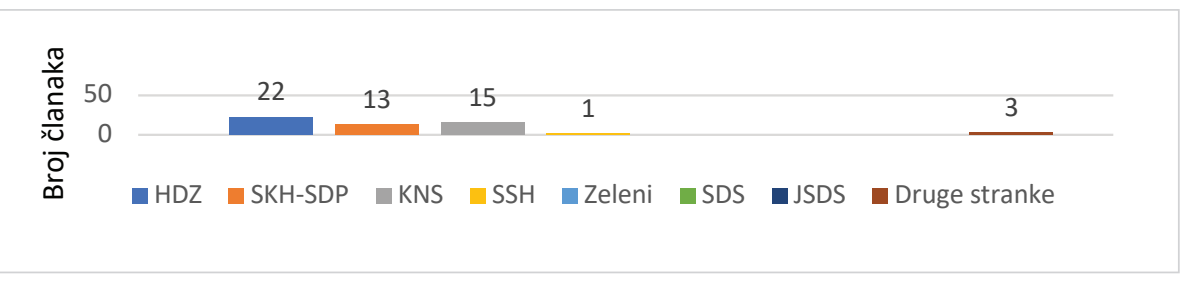

Slobodni tjednik pak marginalizira SKH-SDP, a najveći je prostor dan HDZ-u. Ostale su stranke potpuno marginalizirane, pa tako i u Vjesniku i Večernjem listu znatno zastupljeni SSH. O SDS-u i Evropskoj zelenoj listi se ne govori. 
Tablica 1. Odnos novina prema HDZ-u

\begin{tabular}{|l|c|c|c|c|c|}
\hline Prikaz HDZ-a & $\begin{array}{c}\text { Svi listovi } \\
\mathbf{N = 4 9 8}\end{array}$ & $\begin{array}{c}\text { Večernji list } \\
\mathbf{N}=\mathbf{2 0 5}\end{array}$ & $\begin{array}{c}\text { Vjesnik } \\
\mathbf{N = 2 1 9}\end{array}$ & $\begin{array}{c}\text { Danas } \\
\mathbf{N = 5 1}\end{array}$ & $\begin{array}{c}\text { ST } \\
\mathbf{N = 2 3}\end{array}$ \\
\hline Pozitivno & $15(3 \%)$ & $3(1,5 \%)$ & $2(0,9 \%)$ & $1(2 \%)$ & $9(39,1 \%)$ \\
\hline Negativno & $179(35,9 \%)$ & $67(32,7 \%)$ & $77(35,2 \%)$ & $26(50,1 \%)$ & $9(39,1 \%)$ \\
\hline Neutralno & $286(57,4 \%)$ & $130(63,4 \%)$ & $130(59,4 \%)$ & $21(41,2 \%)$ & $5(21,7 \%)$ \\
\hline Mješovito & $18(3,6 \%)$ & $5(2,4 \%)$ & $10(4,6 \%)$ & $3(5,9 \%)$ & $0(0 \%)$ \\
\hline $\begin{array}{l}\text { Broj članaka u } \\
\text { kojima se ne } \\
\text { govori o HDZ-u }\end{array}$ & 687 & 292 & 361 & 20 & 14 \\
\hline
\end{tabular}

Tablica 2. Odnos novina prema SKH-SDP-u

\begin{tabular}{|l|c|c|c|c|c|}
\hline $\begin{array}{l}\text { Prikaz } \\
\text { SKH-SDP-a }\end{array}$ & $\begin{array}{c}\text { Svi listovi } \\
\mathbf{N}=\mathbf{4 7 5}\end{array}$ & $\begin{array}{c}\text { Večernji list } \\
\mathbf{N}=\mathbf{1 8 9}\end{array}$ & $\begin{array}{c}\text { Vjesnik } \\
\mathbf{N = 2 2 6}\end{array}$ & $\begin{array}{c}\text { Danas } \\
\mathbf{N}=\mathbf{4 6}\end{array}$ & $\begin{array}{c}\text { ST } \\
\mathbf{N}=\mathbf{1 4}\end{array}$ \\
\hline Pozitivno & $38(8 \%)$ & $9(4,8 \%)$ & $19(8,4 \%)$ & $6(13 \%)$ & $4(28,6 \%)$ \\
\hline Negativno & $84(17,7 \%)$ & $31(16,4 \%)$ & $33(14,6 \%)$ & $15(32,6 \%)$ & $5(35,7 \%)$ \\
\hline Neutralno & $343(72,2 \%)$ & $145(76,7 \%)$ & $169(74,8 \%)$ & $25(54,3 \%)$ & $4(28,6 \%)$ \\
\hline Mješovito & $10(2,1 \%)$ & $4(2,1 \%)$ & $5(2,2 \%)$ & $0(0 \%)$ & $1(7,1 \%)$ \\
\hline $\begin{array}{l}\text { Broj članaka } \\
\text { u kojima se } \\
\text { ne govori o } \\
\text { SKH-SDP-u }\end{array}$ & 710 & 309 & 353 & 25 & 23 \\
\hline
\end{tabular}

Tablica 3. Odnos novina prema KNS-u

\begin{tabular}{|l|c|c|c|c|c|}
\hline Prikaz KNS-a & $\begin{array}{c}\text { Svi listovi } \\
\mathbf{N = 4 4 1}\end{array}$ & $\begin{array}{c}\text { Večernji list } \\
\mathbf{N}=\mathbf{1 8 6}\end{array}$ & $\begin{array}{c}\text { Vjesnik } \\
\mathbf{N = 1 9 8}\end{array}$ & $\begin{array}{c}\text { Danas } \\
\mathbf{N = 4 1}\end{array}$ & $\begin{array}{c}\text { ST } \\
\mathbf{N}=\mathbf{1 6}\end{array}$ \\
\hline Pozitivno & $34(7,7 \%)$ & $9(4,8 \%)$ & $10(5,1 \%)$ & $6(14,6 \%)$ & $9(56,3 \%)$ \\
\hline Negativno & $57(12,9 \%)$ & $25(13,4 \%)$ & $22(11,1 \%)$ & $6(14,6 \%)$ & $4(25 \%)$ \\
\hline Neutralno & $345(78,2 \%)$ & $150(80,6 \%)$ & $166(83,8 \%)$ & $26(63,4 \%)$ & $3(18,8 \%)$ \\
\hline Mješovito & $5(1,1 \%)$ & $2(1,1 \%)$ & $0(0 \%)$ & $3(7,3 \%)$ & $0(0 \%)$ \\
\hline $\begin{array}{l}\text { Broj članaka } \\
\text { u kojima se ne } \\
\text { govori o KNS-u }\end{array}$ & 744 & 311 & 382 & 30 & 21 \\
\hline
\end{tabular}

U prikazu stranaka/koalicija korištena su četiri moguća odgovora, pri čemu se neutralnima smatraju članci u kojima novinar ili izvor ne iznose vrijednosne sudove o stranci/koaliciji. Pozitivnim prikazom smatraju se oni članci u kojima novinar i/ili izvor iznose isključivo pozitivne vrijednosne sudove, a negativnim prikazom članci u kojima su iznesene isključivo negativne tvrdnje o stranci/koaliciji. Mješovitim se prikazom smatraju članci u kojima su zastupljeni i negativni i pozitivni sudovi o stranci/koaliciji. HDZ je samo 
15 puta prikazan pozitivno u 498 članaka u kojima se govorilo o njemu, a od tih 15 čak 9 puta u ST-u. U Večernjem listu evidentno postoji pristranost medijskih stavova, koja se očituje u preko dvostruko češćem negativnom prikazu HDZ-a nego KNS-a i SKH-SDP-a. U Vjesniku je taj trend još izraženiji. SKH-SDP je nešto češće od KNS-a negativno prikazivan u Vjesniku i Večernjem listu, ali je nešto češće pozitivno prikazivan u Vjesniku. Danas pokazuje najveću „naklonjenost” KNS-u, koja se ogleda u znatno manjem broju negativnih članaka u odnosu na SKH-SDP, a uvelike se najviše negativno prikazivao $\mathrm{HDZ}$ - u 50,1 \% objava. U ST-u je pak HDZ prikazivan najčešće pozitivno (39,1\%), ali i najčešće negativno (39,1\%). Najmanje je puta negativno prikazan KNS.

Analizirajući njemačke predizborne kampanje od 1990. do 2002., Semetko i Schoenbach pokazali su da su komentari bili više negativni, a izvještavanje usmjereno prema konfliktu, pri praćenju kampanja koje su bile kompetitivne, što upućuje na korelaciju između negativnosti prikaza aktera i kompetitivnosti kampanje. ${ }^{88} \mathrm{U}$ promatranom su slučaju izbori svakako bili kompetitivni te su označavali svojevrsnu prekretnicu. Pozitivnih je komentara bilo manje nego negativnih i neutralnih, a najveći udio pozitivnih komentara zabilježen je u ST-u, kao i najmanji broj neutralnih. Logično je da je to izraženo kod $S T$-a, koji je tabloid. Božidar Novak smatra da pojava ST-a označava „početak ekstremnog žutog tiska" u Hrvatskoj. ${ }^{89}$ Obilježja tabloida su senzacionalizam i personalizacija, pri čemu se personalizacija odnosi na fokusiranost tabloida na privatni život pojedinaca. Pritom tabloidi često pojednostavnjuju, iskrivljuju stvarnost da bi ona dobila senzacionalistički prizvuk i da bi se stvorio skandal..$^{90} S T$ je često iznosio oštre i grube uvrede, klevete i huškačke izjave. Primjerice, splitskoga SDP-ovca Antu Jurjevića Baju nazvali su „sitnim i ameboidnim stvorenjem" u tekstu koji potpisuju „Mafijaši ST”. ${ }^{91}$ Također su objavili intervju s visokim dužnosnikom u NDH Ivom Omrčaninom, u kojemu intervjuirani tvrdi da je Jasenovac „bajka” koju su stvorili Židovi u Hollywoodu te iznosi mnoštvo drugih antisemitskih ocjena. ${ }^{92}$

Za prikaz stranaka bitno je proizlazi li negativan/pozitivan/neutralan/ mješovit prikaz iz autorskoga stava ili iz izbora izvora. Vijesti, izvještaji, proširene vijesti ne bi trebali izražavati osobna stajališta, a za komentare i osvrte to je nužnost. ${ }^{93}$

88 SEMETKO, SCHOENBACH, „News and Elections”.

89 NOVAK, Hrvatsko novinarstvo u 20. stoljeću, 964.

90 SKOVSGAARD, „A Tabloid Mind?”, 200-206; ÖRNEBRING, JÖNSSON, „Tabloid Journalism and the Public Sphere”, 283; ESSER, „Tabloidization of News”, 291-294.

91 MAFIJAŠI ST, „Trakavica zvana 'baja dinastija”, ST, 14. 4. 1990., 4.

92 Ž. LUBUROVIĆ, „Amerika financira Goldsteina”, ST, 14. 4. 1990., 6-7.

93 MALOVIĆ, Osnove novinarstva, 243-244. 
Tablica 4. Prikaz HDZ-a u objavama bez stajališta novinara

\begin{tabular}{|l|c|c|c|c|c|}
\hline $\begin{array}{l}\text { Prikaz HDZ-a } \\
\text { kad novinar } \\
\text { ne izražava } \\
\text { svoje stajalište }\end{array}$ & $\begin{array}{c}\text { Svi listovi } \\
\mathbf{N}=\mathbf{3 8 1}\end{array}$ & $\begin{array}{c}\text { Večernji list } \\
\mathbf{N}=\mathbf{1 7 0}\end{array}$ & $\begin{array}{c}\text { Vjesnik } \\
\mathbf{N}=\mathbf{1 7 9}\end{array}$ & $\begin{array}{c}\text { Danas } \\
\mathbf{N}=\mathbf{2 1}\end{array}$ & $\begin{array}{c}\text { ST } \\
\mathbf{N}=\mathbf{1 1}\end{array}$ \\
\hline Pozitivno & $5(1,3 \%)$ & $1(0,6 \%)$ & $1(0,6 \%)$ & $0(0 \%)$ & $3(27,3 \%)$ \\
\hline Negativno & $118(31 \%)$ & $52(30,6 \%)$ & $56(31,3 \%)$ & $6(28,6 \%)$ & $4(36,4 \%)$ \\
\hline Neutralno & $245(64,3 \%)$ & $115(67,6 \%)$ & $113(63,1 \%)$ & $13(61,9 \%)$ & $4(36,4 \%)$ \\
\hline Mješovito & $13(3,4 \%)$ & $2(1,2 \%)$ & $9(5 \%)$ & $2(9,5 \%)$ & $0(0 \%)$ \\
\hline
\end{tabular}

Tablica 5. Prikaz HDZ-a u objavama sa stajalištem novinara

\begin{tabular}{|l|c|c|c|c|c|}
\hline $\begin{array}{l}\text { Vrijednosni } \\
\text { prikaz HDZ-a } \\
\text { kad novinar } \\
\text { izražava svoje } \\
\text { stajalište }\end{array}$ & $\begin{array}{c}\text { Svi listovi } \\
\mathbf{N}=\mathbf{1 1 7}\end{array}$ & $\begin{array}{c}\text { Večernji list } \\
\mathbf{N}=\mathbf{3 5}\end{array}$ & $\begin{array}{c}\text { Vjesnik } \\
\mathbf{N}=\mathbf{4 0}\end{array}$ & $\begin{array}{c}\text { Danas } \\
\mathbf{N}=\mathbf{3 0}\end{array}$ & $\begin{array}{c}\text { ST } \\
\mathbf{N}=\mathbf{1 2}\end{array}$ \\
\hline Pozitivno & $10(8,5 \%)$ & $2(5,7 \%)$ & $1(2,5 \%)$ & $1(3,3 \%)$ & $6(50 \%)$ \\
\hline Negativno & $61(52,1 \%)$ & $15(42,9 \%)$ & $21(52,5 \%)$ & $20(66,7 \%)$ & $5(41,7 \%)$ \\
\hline Neutralno & $41(35 \%)$ & $15(42,9 \%)$ & $17(42,5 \%)$ & $8(26,7 \%)$ & $1(8,3 \%)$ \\
\hline Mješovito & $5(4,3 \%)$ & $3(8,6 \%)$ & $1(2,5 \%)$ & $1(3,3 \%)$ & $0(0 \%)$ \\
\hline
\end{tabular}

Iz navedenih podataka jasno proizlazi korelacija između negativnoga prikaza HDZ-a i članaka u kojima autor teksta izražava stajalište u svim novinama osim u $S T$-u, u kojemu postoji korelacija između pozitivnoga prikaza HDZ-a i izražavanja autorskoga stava. Utvrđeno je da je u Danasu u člancima u kojima novinar iznosi svoje mišljenje HDZ negativno prikazan u čak 66,7 \% slučajeva.

Tablica 6. Prikaz SKH-SDP-a u objavama bez stajališta novinara

\begin{tabular}{|l|c|c|c|c|c|}
\hline $\begin{array}{l}\text { Prikaz SKH- } \\
\text { SDP-a kad } \\
\text { novinar ne } \\
\text { izražava svoje } \\
\text { stajalište }\end{array}$ & $\begin{array}{c}\text { Svi listovi } \\
\mathbf{N = 3 7 8}\end{array}$ & $\begin{array}{c}\text { Večernji list } \\
\mathbf{N}=\mathbf{1 6 4}\end{array}$ & $\begin{array}{c}\text { Vjesnik } \\
\mathbf{N}=\mathbf{1 9 0}\end{array}$ & $\begin{array}{c}\text { Danas } \\
\mathbf{N}=\mathbf{1 9}\end{array}$ & $\begin{array}{c}\text { ST } \\
\mathbf{N}=\mathbf{5}\end{array}$ \\
\hline Pozitivno & $22(5,8 \%)$ & $5(3 \%)$ & $11(5,8 \%)$ & $3(15,8 \%)$ & $3(60 \%)$ \\
\hline Negativno & $55(14,6 \%)$ & $26(15,9 \%)$ & $23(12,1 \%)$ & $5(26,3 \%)$ & $1(20 \%)$ \\
\hline Neutralno & $293(77,5 \%)$ & $129(78,7 \%)$ & $152(80 \%)$ & $11(57,9 \%)$ & $1(20 \%)$ \\
\hline Mješovito & $8(2,1 \%)$ & $4(2,4 \%)$ & $4(2,1 \%)$ & $0(0 \%)$ & $0(0 \%)$ \\
\hline
\end{tabular}


Tablica 7. Prikaz SKH-SDP-a u objavama sa stajalištem novinara

\begin{tabular}{|c|c|c|c|c|c|}
\hline $\begin{array}{l}\text { Vrijednosni } \\
\text { prikaz } \\
\text { SKH-SDP-a } \\
\text { kad novinar } \\
\text { izražava svoje } \\
\text { stajalište }\end{array}$ & $\begin{array}{l}\text { Svi listovi } \\
\quad \mathbf{N}=97\end{array}$ & $\begin{array}{c}\text { Večernji list } \\
\mathrm{N}=25\end{array}$ & $\begin{array}{l}\text { Vjesnik } \\
\mathrm{N}=36\end{array}$ & $\begin{array}{l}\text { Danas } \\
N=27\end{array}$ & $\begin{array}{c}S T \\
\mathrm{~N}=9\end{array}$ \\
\hline Pozitivno & $16(16,5 \%)$ & $4(16 \%)$ & $8(22,2 \%)$ & $3(11,1 \%)$ & $1(11,1 \%)$ \\
\hline Negativno & $29(29,9 \%)$ & $5(20 \%)$ & $10(27,8 \%)$ & $10(37 \%)$ & $4(44,4 \%)$ \\
\hline Neutralno & $50(51,5 \%)$ & $16(64 \%)$ & $17(47,2 \%)$ & $14(51,9 \%)$ & $3(33,3 \%)$ \\
\hline Mješovito & $2(2,1 \%)$ & $0(0 \%)$ & $1(2,8 \%)$ & $0(0 \%)$ & $1(11,1 \%)$ \\
\hline
\end{tabular}

U prikazu SKH-SDP-a također postoji korelacija između negativnoga prikaza i objava u kojima autor izražava svoje mišljenje, pogotovo u tjedniku $D a-$ nas i u Vjesniku. Veći je udio i pozitivnoga prikaza u Večernjem listu i Vjesni$k u$ kad novinari iznose svoje mišljenje. SKH-SDP je najnegativnije prikazan u ST-ovim člancima s novinarskim stajalištem.

Tablica 8. Prikaz KNS-a u objavama bez stajališta novinara

\begin{tabular}{|l|c|c|c|c|c|}
\hline $\begin{array}{l}\text { Prikaz KNS-a } \\
\text { kad novinar } \\
\text { ne izražava } \\
\text { svoje stajalište }\end{array}$ & $\begin{array}{c}\text { Svi listovi } \\
\mathbf{N}=\mathbf{3 5 8}\end{array}$ & $\begin{array}{c}\text { Večernji list } \\
\mathbf{N}=\mathbf{1 6 0}\end{array}$ & $\begin{array}{c}\text { Vjesnik } \\
\mathbf{N}=\mathbf{1 7 4}\end{array}$ & $\begin{array}{c}\text { Danas } \\
\mathbf{N}=\mathbf{1 5}\end{array}$ & $\begin{array}{c}\text { ST } \\
\mathbf{N}=\mathbf{9}\end{array}$ \\
\hline Pozitivno & $16(4,5 \%)$ & $5(3,1 \%)$ & $5(2,9 \%)$ & $1(6,7 \%)$ & $5(55,6 \%)$ \\
\hline Negativno & $35(9,8 \%)$ & $16(10 \%)$ & $16(9,2 \%)$ & $1(6,7 \%)$ & $2(22,2 \%)$ \\
\hline Neutralno & $304(84,9 \%)$ & $137(85,6 \%)$ & $153(87,9 \%)$ & $12(80 \%)$ & $2(22,2 \%)$ \\
\hline Mješovito & $3(0,8 \%)$ & $2(1,3 \%)$ & $0(0 \%)$ & $1(6,7 \%)$ & $0(0 \%)$ \\
\hline
\end{tabular}

Tablica 9. Prikaz KNS-a u objavama sa stajalištem novinara

\begin{tabular}{|l|c|c|c|c|c|}
\hline $\begin{array}{l}\text { Vrijednosni } \\
\text { prikaz KNS-a } \\
\text { kad novinar } \\
\text { izražava svoje } \\
\text { stajalište }\end{array}$ & $\begin{array}{c}\text { Svi listovi } \\
\mathbf{N = 8 3}\end{array}$ & $\begin{array}{c}\text { Večernji list } \\
\mathbf{N}=\mathbf{2 6}\end{array}$ & $\begin{array}{c}\text { Vjesnik } \\
\mathbf{N}=\mathbf{2 4}\end{array}$ & $\begin{array}{c}\text { Danas } \\
\mathbf{N}=\mathbf{2 6}\end{array}$ & $\begin{array}{c}\text { ST } \\
\mathbf{N}=\mathbf{7}\end{array}$ \\
\hline Pozitivno & $18(21,7 \%)$ & $4(15,4 \%)$ & $5(20,8 \%)$ & $5(19,2 \%)$ & $4(57,1 \%)$ \\
\hline Negativno & $22(26,5 \%)$ & $9(34,6 \%)$ & $6(25 \%)$ & $5(19,2 \%)$ & $2(28,6 \%)$ \\
\hline Neutralno & $41(49,4 \%)$ & $13(50 \%)$ & $13(54,2 \%)$ & $14(53,8 \%)$ & $1(14,3 \%)$ \\
\hline Mješovito & $2(2,4 \%)$ & $0(0 \%)$ & $0(0 \%)$ & $2(7,7 \%)$ & $0(0 \%)$ \\
\hline
\end{tabular}

KNS je također češće negativno nego pozitivno prikazivan u člancima u kojima autori članka iznose mišljenje, osim u ST-u, a u Danasu je zabilježen 
jednak broj pozitivnih i negativnih komentara. Općenito je u takvim člancima uvjerljivo najnegativnije prikazivan HDZ, a najpozitivnije KNS.

Iduća kategorija važna za utvrđivanje postojanja medijske pristranosti jesu članci najavljeni na naslovnici. Naime, oni signaliziraju da je riječ o najvažnijim temama u tom broju novina, a „odabrani naslovi, sažimlju i vrednuju događaj, što uvelike utječe na način na koji čitatelj percipira vijesti”. ${ }^{94}$

Tablica 10. Stranka u fokusu objava najavljenih na naslovnici ${ }^{95}$

\begin{tabular}{|l|c|c|c|c|c|}
\cline { 2 - 6 } \multicolumn{1}{l|}{} & \multicolumn{4}{|c|}{ Novine } \\
\hline $\begin{array}{l}\text { Stranka u } \\
\text { fokusu priloga } \\
\text { najavljenih na } \\
\text { naslovnici }\end{array}$ & $\begin{array}{c}\text { Sve novine } \\
\mathbf{N}=\mathbf{1 3 6}\end{array}$ & $\begin{array}{c}\text { Večernji list } \\
\mathbf{N}=\mathbf{6 6}\end{array}$ & $\begin{array}{c}\text { Vjesnik } \\
\mathbf{N}=\mathbf{4 7}\end{array}$ & $\begin{array}{c}\text { Danas } \\
\mathbf{N}=\mathbf{9}\end{array}$ & $\begin{array}{c}\text { ST } \\
\mathbf{N}=\mathbf{1 4}\end{array}$ \\
\hline HDZ & $34(25 \%)$ & $13(19,7 \%)$ & $11(23,4 \%)$ & $3(33,3 \%)$ & $7(50 \%)$ \\
\hline SKH-SDP & $26(19,1 \%)$ & $14(21,2 \%)$ & $10(21,3 \%)$ & $1(11,1 \%)$ & $1(7,1 \%)$ \\
\hline KNS & $25(18,4 \%)$ & $10(15,2 \%)$ & $10(21,3 \%)$ & $1(11,1 \%)$ & $4(28,6 \%)$ \\
\hline SSH & $2(1,5 \%)$ & $1(1,5 \%)$ & $1(2,1 \%)$ & $0(0 \%)$ & $0(0 \%)$ \\
\hline Zeleni & $0(0 \%)$ & $0(0 \%)$ & $0(0 \%)$ & $0(0 \%)$ & $0(0 \%)$ \\
\hline SDS & $2(1,5 \%)$ & $1(1,5 \%)$ & $1(2,1 \%)$ & $0(0 \%)$ & $0(0 \%)$ \\
\hline JSDS & $0(0 \%)$ & $0(0 \%)$ & $0(0 \%)$ & $0(0 \%)$ & $0(0 \%)$ \\
\hline Druge stranke & $3(2,2 \%)$ & $2(3 \%)$ & $1(2,1 \%)$ & $0(0 \%)$ & $0(0 \%)$ \\
\hline $\begin{array}{l}\text { Više stranaka } \\
\text { u fokusu }\end{array}$ & $25(18,4 \%)$ & $13(19,7 \%)$ & $9(19,1 \%)$ & $3(33,3 \%)$ & $0(0 \%)$ \\
\hline $\begin{array}{l}\text { Stranke su } \\
\text { periferni dio } \\
\text { članka }\end{array}$ & $19(14 \%)$ & $12(18,2 \%)$ & $4(8,5 \%)$ & $1(11,1 \%)$ & $2(14,3 \%)$ \\
\hline
\end{tabular}

„Važnost” drugih stranaka izuzev HDZ-a, SKH-SDP-a i KNS-a za medije dobro prikazuje tablica 10: tri najveće stranke u fokusu su 87 članaka najavljenih na naslovnici, a sve ostale stranke zajedno u samo 7 članaka. U Večernjem listu u fokusu članaka najavljenih na naslovnici od izbornih favorita najčešće je SKH-SDP, a najmanje KNS. U Vjesniku pak postoji gotovo ravnoteža između tri izborna favorita, a u Danasu je HDZ najčešće u fokusu članaka najavljenih na naslovnici, iako takvih članaka u Danasu nije bilo mnogo. U ST-u je pak HDZ-u pridana najveća važnost, a SKH-SDP je izrazito marginaliziran.

94 RAGUŽ, BELUHAN, KOVAČIĆ, „Izvještavanje hrvatskih dnevnih novina o predsjedničkim kandidatima", 83.

95 Stranka u fokusu članka jest ona kojoj je dan najveći prostor u članku. Ako dvije ili više stranaka u objavi zauzimaju podjednako velik prostor, članak spada u kategoriju „više stranaka u fokusu". Ako se pak u članku progovara o određenoj pojavi, fenomenu, ideologiji ili slično, a stranke/koalicije samo se usputno spominju, tada je on kategoriziran kao „stranke su periferni dio objave". 
Ponovno se pokazalo da „vratarska” pristranost postoji zbog nepostojanja reprezentacije manjih stranaka na naslovnici, a dominiraju tri najjače stranke.

Za utvrđivanje „sadržajne” pristranosti pogotovo nam je važan prikaz triju najvećih stranaka/koalicija na naslovnici, odnosno u najvažnijim člancima za promatrane medije.

Grafikon 9. Prikaz HDZ-a u objavama najavljenim na naslovnici

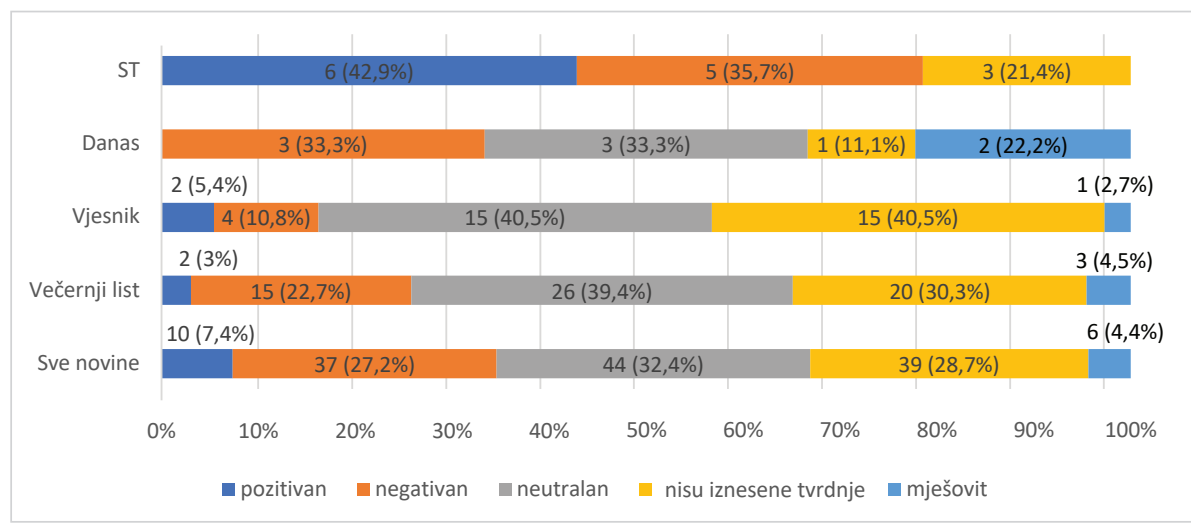

Grafikon 10. Prikaz SKH-SDP-a u objavama najavljenim na naslovnici

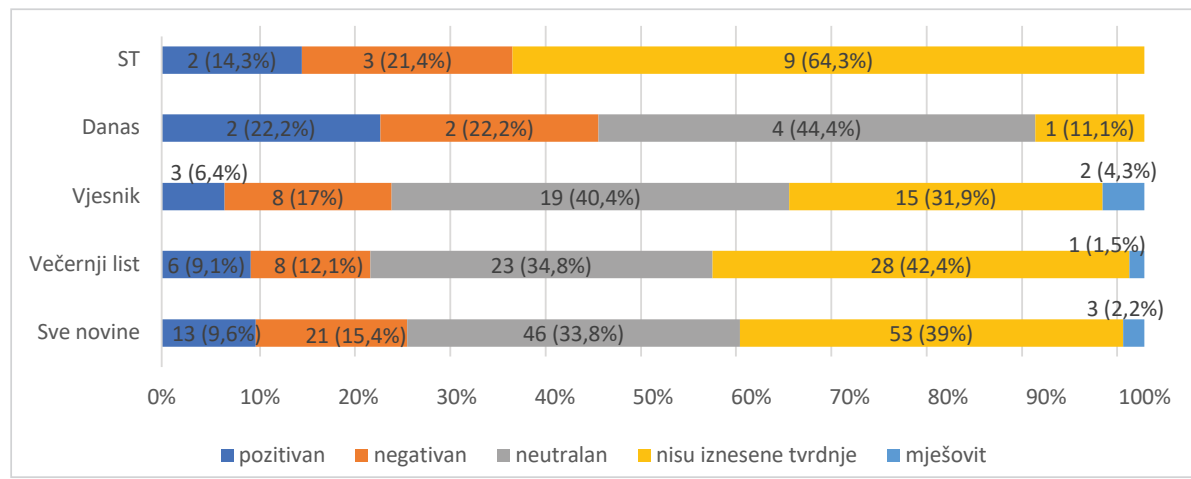

Grafikon 11. Prikaz KNS-a u objavama najavljenim na naslovnici

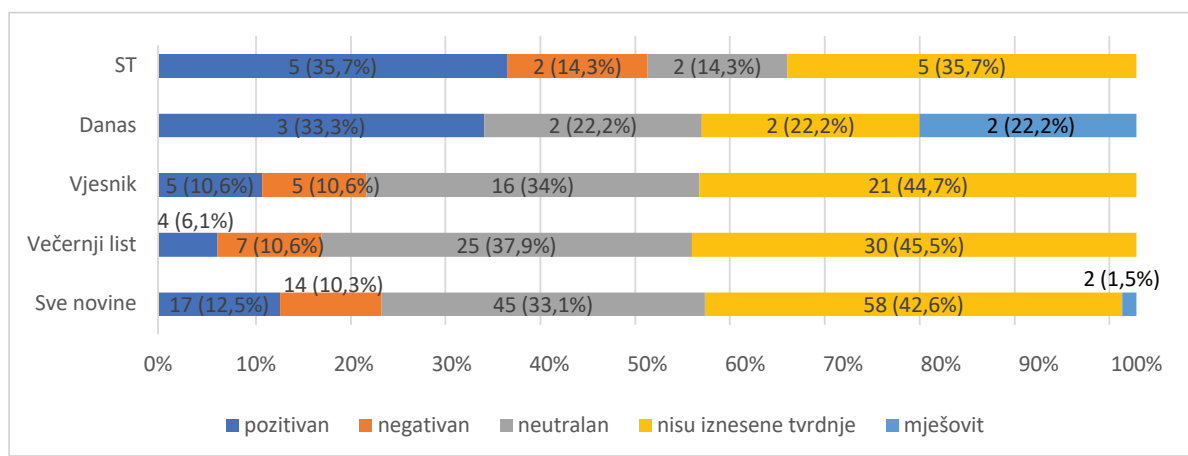


HDZ je uvjerljivo najnegativnije prikazan u „najbitnijim” člancima, odnosno onima najavljenim na naslovnici, a KNS najpozitivnije. Međutim, kad se podaci ne promatraju kumulativno, dolazimo do drugačijih rezultata. Zanimljiva je razlika između Večernjega lista i Vjesnika, koji su inače slično prikazivali stranke u predizbornoj kampanji. Tako je u člancima najavljenim na naslovnici Vjesnika najnegativnije prikazan SKH-SDP, a ne HDZ. Zanimljivo je primijetiti da se od svih stranaka najčešće govori o HDZ-u. Ta je stranka ukupno u ST-u pozitivno prikazana u 9 članaka, od kojih je 6 najavljeno na naslovnici, ali je samo 5 puta prikazana negativno.

Posljednja kategorija ove analize je politički intervju, koji je velika prilika za stranke da izravno predstave svoj program. Stoga je njihova raspoređenost također bitan faktor u utvrđivanju medijske pristranosti.

Tablica 11. Intervjui s političarima

\begin{tabular}{|c|c|c|c|c|}
\hline $\begin{array}{l}\text { Intervjuirana osoba } \\
\text { i datum }\end{array}$ & $\begin{array}{l}\text { Stranka/ } \\
\text { koalicija }\end{array}$ & Novine & $\begin{array}{l}\text { Veličina } \\
\text { članka }\end{array}$ & $\begin{array}{l}\text { Najava članka } \\
\text { na naslovnici }\end{array}$ \\
\hline $\begin{array}{l}\text { Hrvoje Šošić } \\
(3.3 .1990 .)\end{array}$ & $\begin{array}{l}\text { Hrvatska } \\
\text { stranka }\end{array}$ & $\begin{array}{l}\text { Večernji } \\
\text { list }\end{array}$ & Do stranice & $\mathrm{Da}$ \\
\hline $\begin{array}{l}\text { Jure Šonje } \\
(4.3 .1990 .)\end{array}$ & KNS (HSS) & $\begin{array}{l}\text { Večernji } \\
\text { list }\end{array}$ & Do stranice & $\mathrm{Ne}$ \\
\hline $\begin{array}{l}\text { Dag Strpić } \\
(6.3 .1990 .) \\
\end{array}$ & SKH-SDP & $\begin{array}{l}\text { Večernji } \\
\text { list }\end{array}$ & Do stranice & $\mathrm{Da}$ \\
\hline $\begin{array}{l}\text { Jovan Rašković } \\
(24.3 .1990 .)\end{array}$ & SDS & $\begin{array}{l}\text { Večernji } \\
\text { list }\end{array}$ & Do stranice & $\mathrm{Da}$ \\
\hline $\begin{array}{l}\text { Ivica Vrkić } \\
(25.3 .1990 .) \\
\end{array}$ & KNS & $\begin{array}{l}\text { Večernji } \\
\text { list }\end{array}$ & Do stranice & $\mathrm{Ne}$ \\
\hline $\begin{array}{l}\text { Nikola Visković } \\
(1.4 .1990 .)\end{array}$ & $\begin{array}{l}\text { Zelena akcija } \\
\text { Split }\end{array}$ & $\begin{array}{l}\text { Večernji } \\
\text { list }\end{array}$ & $\begin{array}{l}\text { Do pola } \\
\text { stranice }\end{array}$ & $\mathrm{Da}$ \\
\hline $\begin{array}{l}\text { Ante Todorić } \\
(5.4 .1990 .)\end{array}$ & KNS & $\begin{array}{l}\text { Večernji } \\
\text { list }\end{array}$ & Do stranice & $\mathrm{Ne}$ \\
\hline $\begin{array}{l}\text { Ivan Supek } \\
(7.4 .1990 .)\end{array}$ & KNS & $\begin{array}{l}\text { Večernji } \\
\text { list }\end{array}$ & $\begin{array}{l}\text { Do stranice } \\
\text { i pol } \\
\end{array}$ & $\mathrm{Da}$ \\
\hline $\begin{array}{l}\text { Branko Caratan } \\
(14.4 .1990 .)\end{array}$ & SKH-SDP & $\begin{array}{l}\text { Večernji } \\
\text { list }\end{array}$ & Do stranice & $\mathrm{Da}$ \\
\hline $\begin{array}{l}\text { Vladimir Šeks } \\
(14.4 .1990 .)\end{array}$ & HDZ & $\begin{array}{l}\text { Večernji } \\
\text { list }\end{array}$ & Do stranice & $\mathrm{Da}$ \\
\hline $\begin{array}{l}\text { Dražen Budiša } \\
(14.4 .1990 .)\end{array}$ & KNS (HSLS) & $\begin{array}{l}\text { Večernji } \\
\text { list }\end{array}$ & Do stranice & $\mathrm{Da}$ \\
\hline $\begin{array}{l}\text { Dražen Nikolić } \\
(15.4 .1990 .)\end{array}$ & EZL & $\begin{array}{l}\text { Večernji } \\
\text { list }\end{array}$ & $\begin{array}{l}\text { Do pola } \\
\text { stranice }\end{array}$ & $\mathrm{Ne}$ \\
\hline $\begin{array}{l}\text { Jadranko Crnić } \\
(25.2 .1990 .)\end{array}$ & SKH-SDP & Vjesnik & $\begin{array}{l}\text { Do pola } \\
\text { stranice }\end{array}$ & $\mathrm{Ne}$ \\
\hline
\end{tabular}




\begin{tabular}{|c|c|c|c|c|}
\hline $\begin{array}{l}\text { Intervjuirana osoba } \\
\text { i datum }\end{array}$ & $\begin{array}{l}\text { Stranka/ } \\
\text { koalicija }\end{array}$ & Novine & $\begin{array}{l}\text { Veličina } \\
\text { članka }\end{array}$ & $\begin{array}{l}\text { Najava članka } \\
\text { na naslovnici }\end{array}$ \\
\hline $\begin{array}{l}\text { Franjo Tuđman } \\
(25.2 .1990 .)\end{array}$ & HDZ & Vjesnik & Do stranice & $\mathrm{Da}$ \\
\hline $\begin{array}{l}\text { Dag Strpić } \\
(11.3 .1990 .)\end{array}$ & SKH-SDP & Vjesnik & $\begin{array}{l}\text { Do pola } \\
\text { stranice }\end{array}$ & $\mathrm{Ne}$ \\
\hline $\begin{array}{l}\text { Nikola Lapov } \\
(18.3 .1990 .)\end{array}$ & SKH-SDP & Vjesnik & $\begin{array}{l}\text { Do pola } \\
\text { stranice }\end{array}$ & $\mathrm{Da}$ \\
\hline $\begin{array}{l}\text { Slavko Goldstein } \\
(18.3 .1990 .)\end{array}$ & KNS (HSLS) & Vjesnik & Do stranice & $\mathrm{Da}$ \\
\hline $\begin{array}{l}\text { Jovan Rašković } \\
(25.3 .1990 .)\end{array}$ & SDS & Vjesnik & Do stranice & $\mathrm{Da}$ \\
\hline $\begin{array}{l}\text { Inge Perko Šeparović } \\
(25.3 .1990 .)\end{array}$ & EZL & Vjesnik & $\begin{array}{l}\text { Do pola } \\
\text { stranice }\end{array}$ & $\mathrm{Ne}$ \\
\hline $\begin{array}{l}\text { Bruno Langer } \\
(25.3 .1990 .)\end{array}$ & $\begin{array}{l}\text { Nezavisni } \\
\text { kandidat }\end{array}$ & Vjesnik & Do stranice & $\mathrm{Ne}$ \\
\hline $\begin{array}{l}\text { Miroslav Puž } \\
(30.3 .1990 .)\end{array}$ & $\mathrm{SSOH}$ & Vjesnik & $\begin{array}{l}\text { Do pola } \\
\text { stranice }\end{array}$ & $\mathrm{Ne}$ \\
\hline $\begin{array}{l}\text { Antun Vujić } \\
(1.4 .1990 .)\end{array}$ & KNS (SDSH) & Vjesnik & Do stranice & $\mathrm{Ne}$ \\
\hline $\begin{array}{l}\text { Milorad Pupovac } \\
(1.4 .1990 .)\end{array}$ & $\mathrm{SDSH} / \mathrm{J}$ & Vjesnik & $\begin{array}{l}\text { Do pola } \\
\text { stranice }\end{array}$ & $\mathrm{Ne}$ \\
\hline $\begin{array}{l}\text { Vladimir Podrebarac } \\
\text { (6. 4. 1990.) }\end{array}$ & $\begin{array}{l}\text { Savez sindikata } \\
\text { Hrvatske }\end{array}$ & Vjesnik & $\begin{array}{l}\text { Do četvrtine } \\
\text { stranice }\end{array}$ & $\mathrm{Ne}$ \\
\hline $\begin{array}{l}\text { Ivica Račan } \\
(8.4 .1990 .)\end{array}$ & SKH-SDP & Vjesnik & Do stranice & $\mathrm{Da}$ \\
\hline $\begin{array}{l}\text { Ante Miko Tripalo } \\
(8.4 .1990 .)\end{array}$ & KNS & Vjesnik & Do stranice & $\mathrm{Da}$ \\
\hline $\begin{array}{l}\text { Vladimir Veselica } \\
(15.4 .1990 .)\end{array}$ & KNS (HDS) & Vjesnik & Do stranice & $\mathrm{Da}$ \\
\hline $\begin{array}{l}\text { Krešimir Džeba } \\
(15.4 .1990 .)\end{array}$ & KNS & Vjesnik & $\begin{array}{l}\text { Do pola } \\
\text { stranice }\end{array}$ & $\mathrm{Da}$ \\
\hline $\begin{array}{l}\text { Željko Mažar } \\
(15.4 .1990 .)\end{array}$ & SS-SSH & Vjesnik & $\begin{array}{l}\text { Do pola } \\
\text { stranice }\end{array}$ & $\mathrm{Ne}$ \\
\hline $\begin{array}{l}\text { Mile Dakić } \\
(16.4 .1990 .)\end{array}$ & JSDS & Vjesnik & $\begin{array}{l}\text { Do četvrtine } \\
\text { stranice }\end{array}$ & $\mathrm{Ne}$ \\
\hline $\begin{array}{l}\text { Ante Miko Tripalo } \\
(13.3 .1990 .)\end{array}$ & KNS & Danas & $\begin{array}{l}\text { Više od dvije } \\
\text { stranice }\end{array}$ & $\mathrm{Da}$ \\
\hline $\begin{array}{l}\text { Ivan Šiber } \\
(27.3 .1990 .)\end{array}$ & SKH-SDP & Danas & Do stranice & $\mathrm{Ne}$ \\
\hline $\begin{array}{l}\text { Božo Marendić } \\
(3.4 .1990 .)\end{array}$ & SKH-SDP & Danas & $\begin{array}{l}\text { Više od dvije } \\
\text { stranice }\end{array}$ & $\mathrm{Da}$ \\
\hline $\begin{array}{l}\text { Ante Miko Tripalo } \\
(28.2 .1990 .)\end{array}$ & KNS & ST & $\begin{array}{l}\text { Do dvije } \\
\text { stranice }\end{array}$ & $\mathrm{Da}$ \\
\hline
\end{tabular}




\begin{tabular}{|c|c|c|c|c|}
\hline $\begin{array}{l}\text { Intervjuirana osoba } \\
\text { i datum }\end{array}$ & $\begin{array}{l}\text { Stranka/ } \\
\text { koalicija }\end{array}$ & Novine & $\begin{array}{l}\text { Veličina } \\
\text { članka }\end{array}$ & $\begin{array}{l}\text { Najava članka } \\
\text { na naslovnici }\end{array}$ \\
\hline $\begin{array}{l}\text { Vladimir Veselica } \\
(7.3 .1990 .)\end{array}$ & KNS & ST & Do stranice & $\mathrm{Da}$ \\
\hline $\begin{array}{l}\text { Tomislav Đorđević } \\
(7.3 .1990 .)\end{array}$ & SKH-SDP & ST & Do stranice & $\mathrm{Ne}$ \\
\hline $\begin{array}{l}\text { Petar Šale } \\
(21.3 .1990 .)\end{array}$ & $\mathrm{HDZ}$ & ST & $\begin{array}{l}\text { Do dvije } \\
\text { stranice }\end{array}$ & $\mathrm{Da}$ \\
\hline $\begin{array}{l}\text { Petar Šale } \\
(28.3 .1990 .)\end{array}$ & $\mathrm{HDZ}$ & ST & Do stranice & $\mathrm{Da}$ \\
\hline $\begin{array}{l}\text { Aleksandar Broz } \\
(28.3 .1990 .)\end{array}$ & SKH-SDP & ST & $\begin{array}{l}\text { Više od dvije } \\
\text { stranice }\end{array}$ & $\mathrm{Ne}$ \\
\hline $\begin{array}{l}\text { Davorin Rudolf } \\
(11.4 .1990 .)\end{array}$ & KNS & ST & $\begin{array}{l}\text { Do stranice } \\
\text { i pol }\end{array}$ & $\mathrm{Ne}$ \\
\hline $\begin{array}{l}\text { Franjo Tuđman } \\
(18.4 .1990 .)\end{array}$ & $\mathrm{HDZ}$ & ST & $\begin{array}{l}\text { Više od dvije } \\
\text { stranice }\end{array}$ & $\mathrm{Da}$ \\
\hline $\begin{array}{l}\text { Ante Baković } \\
(18.4 .1990 .)\end{array}$ & $\mathrm{HDZ}$ & ST & $\begin{array}{l}\text { Više od dvije } \\
\text { stranice }\end{array}$ & $\mathrm{Da}$ \\
\hline $\begin{array}{l}\text { Ivica Račan } \\
(18.4 .1990 .)\end{array}$ & SKH-SDP & ST & Do stranice & $\mathrm{Ne}$ \\
\hline $\begin{array}{l}\text { Ante Miko Tripalo } \\
(18.4 .1990 .)\end{array}$ & KNS & ST & $\begin{array}{l}\text { Do dvije } \\
\text { stranice }\end{array}$ & $\mathrm{Ne}$ \\
\hline $\begin{array}{l}\text { Silvije Degen } \\
(18.4 .1990 .)\end{array}$ & SS-SSH & ST & $\begin{array}{l}\text { Do dvije } \\
\text { stranice }\end{array}$ & $\mathrm{Ne}$ \\
\hline $\begin{array}{l}\text { Ratimir Veronese } \\
(18.4 .1990 .)\end{array}$ & $\mathrm{HDZ}$ & ST & Do stranice & $\mathrm{Da}$ \\
\hline $\begin{array}{l}\text { Rikard Gumzej } \\
(18.4 .1990 .)\end{array}$ & $\mathrm{HDZ}$ & ST & Do stranice & $\mathrm{Ne}$ \\
\hline $\begin{array}{l}\text { Boris Buzančić } \\
(18.4 .1990 .)\end{array}$ & $\mathrm{HDZ}$ & ST & $\begin{array}{l}\text { Do dvije } \\
\text { stranice }\end{array}$ & $\mathrm{Ne}$ \\
\hline
\end{tabular}

Od 12 političkih intervjua u Večernjem listu čak ih je 5 bilo s članovima KNS-a. Međutim, samo su 2 bila najavljena na naslovnici, a objavljena su tek 2 intervjua s SDP-ovim stranačkim prvacima, pri čemu su oba najavljena na naslovnoj stranici, i samo jedan s članom HDZ-a. To pokazuje očito privilegiranje KNS-a u odnosu na SKH-SDP i HDZ. Intervjui s vođama manjih stranaka zauzimali su manji prostor (do pola stranice), s iznimkom intervjua s Jovanom Raškovićem.

Vjesnik je objavio 18 političkih intervjua, najviše (5) s članovima KNS-a, od kojih su čak 4 najavljena na naslovnici te su zauzimali između pola i cijele stranice. Četiri intervjua objavljena su s članovima SKH-SDP-a, ali samo je jedan od njih bio veličine do stranice, a 2 su najavljena na naslovnici. HDZ je pak, kao u Večernjem listu, marginaliziran jer je objavljen samo intervju s Franjom Tuđmanom, i to na samom početku kampanje, koji je bio najav- 
ljen na naslovnici. Drugim je strankama dan poveći prostor jer je čak 8 od 18 intervjua (44,4 \%) posvećeno strankama koje nisu bile „izborni favoriti”. Među intervjuiranima je ponovno predsjednik SDS-a Jovan Rašković, jedan nezavisni kandidat (Bruno Langer) te predstavnici EZL-a, SSOH i SDSH/J te Saveza sindikata Hrvatske, SSH-a i JSDS-a. Međutim, ti intervjui, s iznimkom onoga s Raškovićem, nisu bili najavljeni na naslovnici te su većinom manji od pola stranice, osim intervjua s Langerom i Raškovićem. Kad bi se SKH-SDP-u dodale bivše društveno-političke organizacije (SS-SSH, SSOH, Savez sindikata Hrvatske), dobivamo 7 intervjua s pripadnicima vladajućih opcija.

Danas je objavio samo 3 intervjua, i to 2 s članovima SKH-SDP-a i jedan s čelnikom KNS-a, ali je bitno istaknuti da je Božo Marendić, iako član SKH-SDP, intervjuiran u svojstvu ministra savezne vlade. ST je objavio čak 15 političkih intervjua, od kojih 8 u posljednjem broju. Potpuno su marginalizirane manje stranke, izuzev SSH-a s obzirom na to da je objavljen razgovor sa Silvijem Degenom, kandidatom SSH-a. Do posljednjega broja 3 su intervjua napravljena s pripadnicima KNS-a, 2 s pripadnicima HDZ-a i 2 s pripadnicima SKH-SDP-a. Ti intervjui često su imali panegirički prizvuk. Primjerice, u prvom intervjuu s Mikom Tripalom, objavljenom u prvom broju ST-a, novinar Jurica Kerbler navodi da Tripalo „u 19 dugih godina potpune političke izolacije nije nagomilao mržnju, bijes, osvetoljubivost, nego više od toga viziju da Jugoslavija mora zajedno”. Sugestivni naslov članka glasio je „Miko Tripalo, čovjek za ovo vrijeme?". ${ }^{96} \mathrm{U}$ istom je broju objavljena i recenzija njegovih memoara, s krajnje pozitivnim prikazom Tripala. ${ }^{97}$ Do posljednjega broja ST-a HDZ je prikazivan pretežito negativno. Primjerice, Kerbler je napisao da je Tuđman rekao da su „Židovi bili ustaški cinkaroši u Jasenovcu”, da je Šeks poručio kako će HDZ „milom ili silom skloniti svakoga tko im se nađe na putu" itd. ${ }^{98}$ Željko Luburović optužio je pak Tuđmana da je plagijator i boljševik te ga je usporedio s Miloševićem. ${ }^{99}$ Međutim, u posljednjem je broju objavljeno čak 5 intervjua s članovima HDZ-a (3 najavljena na naslovnici), a neki su imali uistinu agitacijsko-promotivna obilježja. Intervju s Tuđmanom objavljen je na tri stranice, kao i s članom predsjedništva don Antom Bakovićem, a novinar Ivan Ostoja u intervjuu se Tuđmanu obraćao s „doktore”: „Doktore, Vaša aktivnost opčinjava, jer je vidljivo da ste u svakom trenutku prisutni tamo gdje to želite biti. Veliki ste borac i to je odlika koja nedostaje mnogim postavljenim vođama koji inače prijete tenkovima, jer oni nemaju što drugo reći." 100

Ispod jedne fotografije u članku pisalo je: „Ovdje u baraci HDZ-a u Savskoj 16 [sjedište HDZ-a, op. a.] kroji se bolja Hrvatska, a i jugoslavenska, bu-

96 J. KERBLER, „Miko Tripalo, čovjek za ovo vrijeme?”, ST, 28. 2. 1990., 12.

97 DŽ. HUSIĆ, „Veteran nepomućenih ideala”, ST, 28. 2. 1990., 14.

98 J. KERBLER, „Tuđmanove karte na stolu”, ST, 28. 2. 1990., 5.

99 Ž. LUBUROVIĆ, „(Ne)djelo izašlo na vidjelo”, ST, 7. 3. 1990., 13.

100 I. OSTOJA, „Dogovor kuću gradi”, ST, 18. 4. 1990., 3. 
dućnost."101 Ostoja na kraju intervjua, nakon Tuđmanove tvrdnje da će HDZ pobijediti u prvom krugu u barem $60 \%$ izbornih jedinica te da je pobjeda zajamčena, odgovara: „Odlično, 25. travnja u Splitu će se održati pobjedničko slavlje s gostima Ćirom Blaževićem, Prljavim kazalištem i Vama koji se pojavljujete na samom finalu u helikopteru”, na što Tuđman odgovara: „Pristajem”, a Ostoja intervju završava riječima: „Doktore, do 25. travnja u Splitu." ${ }^{102}$ Ovaj kratki kvalitativni ekskurs bio je nužan da bi se pokazalo da je postojala stranačka pristranost u korist HDZ-a u ST-u. Naime, iako je KNS jednako puta pozitivno prikazan kao HDZ, a manje puta negativno, ST je upravo u posljednjem, ključnom broju pred izbore dao otvorenu podršku HDZ-u i izravno promovirao tu stranku.

\section{Rasprava}

Svi promatrani mediji, a pogotovo tjednici Danas i $S T$, najviše su pisali o izbornim favoritima - HDZ-u, SKH-SDP-u i KNS-u. Poštujući kriterij relevantnosti stranke predstavljen u prethodnom poglavlju, zaključeno je da je i SSH relevantna stranka jer ima koalicijski potencijal. Uistinu, ta stranka dobivala je mnogo veći prostor od ostalih manjih stranaka u Večernjem listu i Vjesniku, ali gotovo da i nije dobivala prostor u ST-u i Danasu. U pisanju tih dvaju tjednika gotovo „ne postoje” druge stranke osim tri izborna favorita. U najvažnijim člancima, odnosno objavama najavljenim na naslovnici, manje su stranke još manje zastupljene u svim novinama, a intervjui s nerelevantnim strankama bili su raritet. Stoga možemo zaključiti da je hipoteza o postojanju „vratarske” pristranosti (H2) potvrđena istraživanjem.

Vjesnik i Večernji list podjednako su često pisali o tri najveće stranke, ali su dosta rjeđe navođene izjave HDZ-a, a radikalno je manje političkih intervjua s članovima HDZ-a objavljeno u tim novinama. Stoga možemo reći da je postojala sadržajna pristranost na štetu HDZ-a u ta dva dnevnika. Također, zbog u usporedbi s Danasom i ST-om izrazito velikoga broja članaka posvećenih SSH-u, možemo ustvrditi da je neformalni vladajući blok bio privilegiran. SSH je ipak sve do 10. ožujka bio vlasnik Vjesnika, pa ta činjenica nije iznenađujuća. U tjedniku Danas nije postojala sadržajna pristranost jer se o tri najjače stranke pisalo u podjednako članaka te su u sličnom broju članaka citirani članovi izbornih favorita. Višak vijesti posvećenih HDZ-u, u kojima je HDZ bio u fokusu članka, u ovom slučaju može biti objašnjen vrijednošću konflikta jer je upravo HDZ najnegativnije prikazivana opcija u Danasu. ${ }^{103}$ Kako navodi Malović, medijima je „sukob zanimljiviji od slaganja”. ${ }^{104}$ U ST-u je pak potpuno marginaliziran SKH-SDP, a sadržajna pristranost postoji u

\footnotetext{
101 Isto, 4.

102 Isto, 5.

103 VAN DALEN, „Structural Bias in Cross-National Perspective”, 35-36.

104 MALOVIĆ, Osnove novinarstva, 39.
} 
korist HDZ-a. Pokazalo se da se obrasci sadržajne pristranosti razlikuju ovisno o promatranim novinama. Međutim, treća je hipoteza (H3) djelomično potvrđena budući da sadržajna pristranost nije postojala u tjedniku Danas.

Pristranost medijskih stavova postoji u Večernjem listu i Vjesniku, a ta dva dnevnika na sličan način održavaju tu vrstu medijske pristranosti. Dok su KNS i SKH-SDP prikazivani slično, HDZ je prikazivan znatno negativnije, zbog čega postoji pristranost medijskih stavova nauštrb HDZ-a. Danas je pak pisao izrazito negativno o HDZ-u, manje negativno o SKH-SDP-u, a najnaklonjeniji je bio KNS-u. Sveukupno gledano, HDZ je uvelike najnegativnije prikazivan u Večernjem listu, Vjesniku i Danasu, a SKH-SDP u ST-u. Pokazalo se dakle da je u kampanji postojao medijski pluralizam te da su promatrani mediji različito prikazivali aktere kampanje. Zanimljivo je primijetiti vrlo slične obrasce praćenja kampanje u Večernjem listu i Vjesniku, najvažnijim dnevnim novinama u Hrvatskoj, što se očituje u davanju najvećega prostora neformalnom vladajućem bloku. Dokazano je u više zemalja da stranke na vlasti dobivaju više medijskoga prostora od izazivača. ${ }^{105}$ No u ovom slučaju najveće dnevne novine nisu se usmjerile na promociju vladajućih te se prikaz SKH-SDP-a nije mnogo razlikovao od prikaza KNS-a, iako je u usporedbi s HDZ-om prikaz vladajućih drastično bolji.

Danas je krajem 80-ih, riječima B. Novaka, bio „zastava liberalne Hrvatske koja je težila demokraciji i višestranačju". ${ }^{106}$ Stoga nije začuđujuća podrška Danasa centrističkoj koaliciji. ST je, kako je pokazano, u posljednjem broju napravio kopernikanski zaokret i otvoreno promicao HDZ. ST je prvi privatni medij u Socijalističkoj Republici Hrvatskoj te je, dakako, funkcionirao na tržišnim osnovama. Moguće je da je upravo ta činjenica povezana sa spomenutim zaokretom. Naime, medijska pristranost može biti strategija medija koji žele maksimizirati svoj profit jer time odgovaraju na preferencije korisnika. Da bi zadovoljili svoje korisnike, mediji postaju pristrani i ne prenose informacije o drugoj strani koje ne odgovaraju njihovim čitateljima ${ }^{107}$ Ako postoji konkurencija, za neke će medije „pristrani” sadržaji biti izrazito profitabilni. ${ }^{108}$ Preostala tri promatrana medija kritički su prikazivala HDZ, a postojao je velik broj pristaša HDZ-a koji su zasigurno „tražili” alternativni pogled. Potvrdilo se da se, kako ističu Örnebring i Jönsson, tabloidi pozicioniraju kao alternativa mainstreamu i tako postaju alternativna javna sfera. ${ }^{109}$ Pristranost medijskih stavova postoji u svim promatranim tjednicima te se manifestirala na drugačiji način, zbog čega je potvrđena četvrta hipoteza $(\mathrm{H} 4)$.

${ }^{105}$ HOPMANN et al., „Party Media Agenda-Setting”, 176.

106 NOVAK, Hrvatsko novinarstvo u 20. stoljeću, 805. Pojam „liberalno” ne bi trebao u ovom kontekstu biti shvaćen kao uobličenje ideologije liberalizma, nego kao relacijska oznaka u odnosu na ideologiju vladajuće stranke u Socijalističkoj Republici Hrvatskoj.

107 BERNHARDT, KRASA, POLBORN, „Political Polarization and the Electoral Effects of Media Bias".

108 Isto, 1093.

109 ÖRNEBRING, JÖNSSON, „Tabloid Journalism and the Public Sphere”. 
„Vratarska” pristranost, sadržajna pristranost i pristranost medijskih stavova vrste su medijske pristranosti koje su definirane u prethodnom poglavlju. Budući da je potvrđeno postojanje svih triju istraživanih medijskih pristranosti, u svim analiziranim medijima, uz iznimku nepostojanja sadržajne pristranosti u Danasu, zaključuje se da je postojala i medijska pristranost per se te je prva hipoteza (H1) potvrđena.

Nastavno na najnegativniji prikaz HDZ-a u tri promatrana medija postavlja se pitanje koliki su utjecaj mediji imali na odluku birača, o čemu ne postoje empirijska istraživanja. Kako navodi Voltmer, za vrijeme prvih izbora većina građana, s mogućom iznimkom pristaša vladajuće stranke i onih koji su aktivno sudjelovali kao opozicija režimu, odlučuje bez oslanjanja na „dugogodišnja uvjerenja i političko opredjeljenje". ${ }^{110}$ Stoga Voltmer tvrdi da uloga medija u takvim slučajevima uključuje u određenoj mjeri „oblikovanje i promjenu građanske orijentacije i ponašanja". ${ }^{111}$ Ako su hrvatski mediji i imali takvu ulogu, očito je da su na ishod izbora utjecali ponajviše tradicionalni načini komunikacije i prenošenja poruka. Izbore je riječima obilježilo „negativno opredjeljenje”, a opozicijske su stranke bile „antisistemski i delegitimacijski usmjerene”. ${ }^{112}$ Što su veće podjele u društvu i izbornom tijelu, odnosno što su veći konflikti općenito, manja je mogućnost medija da utječu na izborne rezultate. ${ }^{113}$ Takva je situacija postojala u Hrvatskoj za vrijeme izbora 1990. godine. Također, ako birači smatraju ishod izbora važnim, što na promatranim izborima svakako jest slučaj jer je riječ o prekretnici, bit će više politički aktivirani, pa će se shodno tome manje oslanjati na medije pri donošenju odluke. Mediji su važniji faktor u stabilnim, konsolidiranim demokracijama u kojima ne postoje društvene tenzije i gdje je razina političke aktiviranosti mala, među ostalim i zato što život pojedinca nije izravno pogođen ishodom izbora. ${ }^{114}$

Općenito je za vrijeme izbora velik broj hrvatskih građana bio učlanjen u političke stranke. Prema procjeni Slavena Letice, u strankama je bilo $15 \%$ biračkoga tijela, odnosno pola milijuna stanovnika Hrvatske. ${ }^{115}$ Čini se vjerojatnim da se građani nakon gotovo polustoljetne partijske kontrole medija nisu uzdali u „kompromitirane” medije, a pobjeda HDZ-a u prvom krugu izbora, usprkos najnegativnijem prikazu, s iznimkom $S T$-a, to i pokazuje. Ipak je HDZ dobio velik prostor, a negativni komentari mogli su biti i kontraproduktivni. Pozitivan učinak negativnoga publiciteta za onoga koga mediji kritiziraju zabilježen je i u drugim tranzicijskim slučajevima. Jakubowicz je pokazao da je poljska televizija davala mnogo veći prostor vladajućoj stranci ispred opozicijske Solidarnosti. Međutim, „kvaliteta izborne propagande bila

\footnotetext{
110 VOLTMER, „The Mass Media and the Dynamics of Political Communication”, 13.

111 Isto.

112 GRDEŠIĆ, „Izbori u Hrvatskoj”, 79.

113 JAKUBOWICZ, „Television and Elections in Post-1989 Poland”, 135.

114 Isto.

115 S. LETICA, „Crven, zelen, plav”, Danas (Zagreb), 20. 3. 1990., 18.
} 
je od drugorazredne važnosti, u najbolju ruku, pa se tako i njezin utjecaj na izborne rezultate ne čini pretjerano velikim". ${ }^{116}$

U vrijeme kampanje održao se i miting na Petrovoj gori, koji je bio evidentna manifestacija agresivnoga srpskog nacionalizma u Hrvatskoj, a organizirali su ga skupštine općina Vojnić i Vrginmost te JSDS. U Benkovcu je 18. ožujka na osnivačkoj skupštini HDZ-a došlo do sukoba s mjesnim Srbima koji su ometali skup, a Boško Čubrilović krenuo je prema Tuđmanu i izvadio plinski pištolj, što je dio medija tada osudio kao pokušaj atentata na Tuđmana. U vrijeme kada je bio potreban otpor ekspanzionističkom srpskom nacionalizmu, birači su očito u HDZ-u prepoznali stranku koja se tome najodlučnije odupire. ${ }^{117}$ Zato Pauković zaključuje da su „napadi na HDZ sve većem broju građana u Hrvatskoj pokazivali da upravo ta stranka najjasnije i najodlučnije brani hrvatske interese". ${ }^{118}$

\section{Zaključak}

Cilj istraživanja bio je utvrditi postoji li medijska pristranost u praćenju predizborne kampanje te postoje li razlike u praćenju kampanje među promatranim medijima. Pokazalo se da medijska pristranost postoji te da su promatrani mediji različito prikazivali stranke/koalicije u predizbornoj kampanji prvoga kruga hrvatskih parlamentarnih izbora 1990. godine. Pokazano je na koji se način početak tranzicije u Hrvatskoj razlikuje od iskustava drugih socijalističkih zemalja te koji su procesi prethodili višestranačju i demokraciji. Nakon toga su predstavljene stranke i koalicije koje su se natjecale na izborima u travnju 1990., kao i izborni zakon prema kojem su izbori održani. Mediji imaju vrlo važnu ulogu u tranziciji i začetku novoga demokratskog sustava kao pružatelj informacija građanima o nepoznatim procesima, ali i u predstavljanju kandidata, stranaka i stranačkih programa. Pritom je važna činjenica da su promatrani mediji, s iznimkom ST-a, ,izrasli” u socijalističkom sustavu te su novinari u njemu formirani i u njemu su djelovali kao poluga vlasti režima dobrim dijelom njegova postojanja. Kako je apostrofirano, mediji imaju bitnu ulogu u predstavljanju kandidata i stranaka. Selekcijom i „puštanjem” određenih stranaka kroz „vrata”, a onemogućavanjem „ulaza” drugim strankama svakako mogu utjecati na percepciju i informiranost birača, iako se pokazalo da medijski utjecaj na biračke odluke nije bio presudan. U radu je definirano što je medijska pristranost i testirano postoje li „vratarska" pristranost, sadržajna pristranost i pristranost medijskih stavova u praćenju predizborne kampanje prvih slobodnih izbora u Hrvatskoj 1990. točnije njihova prvoga kruga. Provedenom kvantitativnom analizom sadržaja 1185 članaka u razdoblju predizborne kampanje potvrđene su prva, druga i

\footnotetext{
116 JAKUBOWICZ, „Television and Elections in Post-1989 Poland”, 141.

117 PAUKOVIĆ, Usred oluje, 159.

${ }_{118}$ Isto.
} 
četvrta hipoteza, a treća je djelomično potvrđena. Utvrđeno je da je „vratarska" pristranost svojstvena svim analiziranim medijima, iako je u tjednicima (Danas i ST) izraženija nego u dnevnim novinama (Večernji list i Vjesnik). Sadržajna pristranost razlikovala se ovisno o promatranom mediju. Tako je u Vjesniku i Večernjem listu marginaliziran HDZ, a SKH-SDP, kada mu se pribroji neformalni koalicijski partner SS-SSH, dobio je najveći prostor. S druge strane u tjedniku Danas nije postojala sadržajna pristranost, dok je u ST-u marginaliziran SKH-SDP, a najveći je prostor dan HDZ-u. Večernji list, Vjesnik i Danas najnegativnije su izvještavali o HDZ-u, dok je ST najnegativnije izvještavao o SKH-SDP-u, a najpozitivnije o HDZ-u. Danas je najpozitivnije pisao o KNS-u, a u Vjesniku i Večernjem listu KNS i SKH-SDP prikazani su na sličan način.

Sadržajna pristranost u korist vladajućih u Vjesniku i Večernjem listu objašnjiva je dugogodišnjom vezanošću tih listova za komunistički režim, a Danasova naklonost KNS-u liberalnijom orijentacijom toga tjednika. S druge strane tabloid ST „mijenjao” je strane tijekom kampanje te je za njegovo podržavanje HDZ-a ponuđeno ekonomsko objašnjenje, odnosno pretpostavlja se da su, kao prva privatna tiskovina, podržavali HDZ jer su od toga imali najveću financijsku korist. Kako navode Riffe, Lacy i Fico, kvantitativna analiza sadržaja zadržava se na analizi manifestnoga sadržaja, a ne proučava latentni sadržaj medijske poruke. ${ }^{119}$ Drugim riječima, proučavaju se denotativna, a ne konotativna značenja. Izostanak afirmativnih komentara o HDZ-u u Vjesniku, Večernjem listu i Danasu može se objasniti pritiskom redakcije, prevladavajućim društvenim normama, novinarskom kulturom i konformizmom. Konotativna značenja komentara trebalo bi obraditi kvalitativnim istraživanjem. Naime, primijećeno je da su neki komentatori u promatranim novinama „branili” HDZ od ocjena o krajnje desnoj ili čak fašističkoj stranci. Međutim, oni najčešće nisu o HDZ-u pisali pozitivno, nego su govorili o „pretjerivanjima” takvih navoda. Iskustvo novinara u socijalizmu, u kojemu je država bila vlasnik medija te je čvrsto kontrolirala pisanje medija, dok je SSH bio vlasnik Vjesnika čak i na početku kampanje, zasigurno je utjecalo na takve tendencije.

\section{Tisak}

Danas (Zagreb), 1990.

Slobodni tjednik (Split), 1990.

Večernji list (Zagreb), 1990.

Vjesnik (Zagreb), 1990.

119 RIFFE, LACY, FICO, Analyzing Media Messages, 29-30. 


\section{Literatura}

BERNHARDT, Dan; KRASA, Stefan; POLBORN, Mattias. „Political Polarization and the Electoral Effects of Media Bias”. Journal of Public Economics 92 (2008), br. 5-6: 1092-1104.

BUDIMIR, Davorka. Politička elita u Hrvatskoj 1986. - 1990. Zagreb: Vlastita naklada, 2018.

BUDIMIR, Davorka. Politička elita u Hrvatskoj 1990. - 2000. Zagreb: Vlastita naklada, 2017.

D’ALESSIO, Dave; ALLEN, Mike. „Media Bias in Presidential Elections: A Meta Analysis”. Journal of Communication 50 (2000), br. 4: 133-156.

ENTMAN, Robert M. „Framing Bias: Media in the Distribution of Power”. Journal of Communication 57 (2007), br. 1: 163-173.

ESSER, Frank. „Tabloidization of News: A Comparative Analysis of Anglo-American and German Press Journalism". European Journal of Communication 14 (1999), br. 3: 291-324.

GRDEŠIĆ, Ivan. „Izbori u Hrvatskoj: birači, vrednovanja, preferencije”. U: Hrvatska u izborima '90, ur. Ivan Grdešić, Mirjana Kasapović, Ivan Šiber i Nenad Zakošek. Zagreb: Naprijed, 1991, 49-97.

GROELING, Tim. „Media Bias by the Numbers: Challenges and Opportunities in the Empirical Study of Partisan News". Annual Review of Political Science 16 (2013), br. 1: 129-151.

GROSECLOSE, Tim; MILYO, Jeffrey. „A Measure of Media Bias”. The Quarterly Journal of Economics 120 (2005), br. 4: 1191-1237.

GROSS, Peter. „Between Reality and Dream: Eastern European Media Transition, Transformation, Consolidation, and Integration”. East European Politics and Societies 18 (2004), br. 1: 110-131.

HOPMANN, David Nicolas; ELMELUND-PRÆSTEKÆ, Christian; VLIEGENTHART, Rens; DE VREESE, Claes H.; ALBÆK, Erik. „Party Media Agenda-Setting: How Parties Influence Election News Coverage”. Party Politics 18 (2012), br. 2: 173-191.

HUNTINGTON, Samuel P. Treći talas: demokratizacija na izmaku dvadesetog veka. Preveo Branimir Gligorić. Zagreb; Podgorica: Politička kultura; CID, 2004.

JAKUBOWICZ, Karol. „Media Within and Without the State: Press Freedom in Eastern Europe”. Journal of Communication 45 (1995), br. 4: 125-139.

JAKUBOWICZ, Karol. „Television and Elections in Post-1989 Poland: How Powerful Is the Medium?". U: Politics, Media and Modern Democracy, ur. David L. Swanson i Paolo Mancini. Praeger: Westport, 1996, 129-154.

KASAPOVIĆ, Mirjana. „Strukturna i dinamička obilježja političkog prostora i izbori”. U: Hrvatska u izborima '90, ur. Ivan Grdešić, Mirjana Kasapović, Ivan Šiber i Nenad Zakošek. Zagreb: Naprijed, 1991, 15-48. 
KOLSTØ, Pål, ur. Media Discourse and the Yugoslav Conflicts: Representations of Self and Other. Farnham: Ashgate, 2009.

KOTKIN, Stephen; GROSS, Jan T. Necivilno društvo: 1989. i pad komunističkog poretka. Prevela Petra Petrač. Zagreb: Alfa, 2012.

KUNCZIK, Michael; ZIPFEL, Astrid. Uvod u znanost o medijima i komunikologiju. Zagreb: Zaklada Friedrich Ebert, 2006.

LOVELESS, Matthew. „Media Dependency: Mass Media as Sources of Information in the Democratizing Countries of Central and Eastern Europe". Democratisation 15 (2008), br. 1: 162-183.

MALOVIĆ, Stjepan. Osnove novinarstva. Zagreb: Golden marketing, 2005.

MANCINI, Paolo; SWANSON, David L. „Television, Campaigning, and Elections in the Soviet Union and Post-Soviet Russia". U: Politics, Media and Modern Democracy, ur. David L. Swanson i Paolo Mancini. Praeger: Westport, 1996, 107-129.

MCQUAIL, Dennis. McQuail's Mass Communication Theory. London: Sage, ${ }^{6} 2010$.

MIHALJEVIĆ, Josip. „Liberalizacija i razvoj medija u komunističkoj Hrvatskoj 1960-ih i na početku 1970-ih". Društvena istraživanja 24 (2015), br. 2: 239-258.

NOVAK, Božidar. Hrvatsko novinarstvo u 20. stoljeću. Zagreb: Golden marketing, 2005.

NOVAK, Božidar. „Novinstvo“. U: Almanah hrvatskoga tiskarstva, nakladništva, novinstva, bibliotekarstva i knjižarstva s adresarom, ur. Branko Franjić. Zagreb: Horizont Press; Kratis, 1997, 130-238.

ÖRNEBRING, Henrik; JÖNSSON, Anna Maria. „Tabloid Journalism and the Public Sphere: A Historical Perspective on Tabloid Journalism". Journalism Studies 5 (2004), br. 3: 283-295.

PAUKOVIĆ, Davor. „Predizborna kampanja u Hrvatskoj 1990. u svjetlu hrvatskog i srpskog novinstva”. Časopis za suvremenu povijest 40 (2008), br. 1: 13-30.

PAUKOVIĆ, Davor. Usred oluje. Politička tranzicija u Hrvatskoj 1989./90. Zagreb: Srednja Europa, 2018.

PERUŠKO, Zrinjka. „Mediji i civilne vrijednosti”. U: Demokratska tranzicija u Hrvatskoj, ur. Sabrina P. Ramet i Davorka Matić. Zagreb: Alineja, 2006, 35-64.

PODOLNJAK, Robert. „Hrvatsko izborno zakonodavstvo: moguće i nužne promjene". Zbornik radova Pravnog fakulteta u Splitu 45 (2008), br. 2: 305-343.

RAGUŽ, Anđelka; BELUHAN, Matej; KOVAČIĆ, Silvija. „Izvještavanje hrvatskih dnevnih novina o predsjedničkim kandidatima tijekom predizborne kampanje 2014./2015.” Medijska istraživanja 21 (2015), br. 2: 79-107. 
RIFFE, Daniel; LACY, Stephen; FICO, Frederick. Analyzing Media Messages: Using Quantitative Content Analysis in Research. New York; London: Routledge, ${ }^{3} 2014$.

SARTORI, Giovanni. Parties and Party Systems: A Framework for Analysis. Cambridge: Cambridge University Press, 1976.

SEMETKO, Holli A.; SCHOENBACH, Klaus. „News and Elections: German Bundestag Campaigns in the Bild, 1990-2002". Harvard International Journal of Press/Politics 8 (2003), br. 1: 54-69.

SKOVSGAARD, Morten. „A Tabloid Mind? Professional Values and Organizational Pressures as Explanations of Tabloid Journalism". Media, Culture \& Society 36 (2014), br. 2: 200-218.

SMAELE, Hedwig De. "In the Name of Democracy': The Paradox of Democracy and Press Freedom in post-Communist Russia". U: Mass Media and Political Communication in New Democracies, ur. Katrin Voltmer. London; New York: Routledge, 2004, 35-48.

SNYDER, James M.; STRÖMBERG, David. „Press Coverage and Political Accountability". Journal of Political Economy 118 (2010), br. 2: 355-408.

SOEBERG, Marius. „Hrvatska nakon 1989. godine: HDZ i politika tranzicije". U: Demokratska tranzicija u Hrvatskoj, ur. Sabrina P. Ramet i Davorka Matić. Zagreb: Alineja, 2006, 35-64.

ŠIBER, Ivan. „Nacionalna, vrijednosna i ideologijska uvjetovanost stranačkog izbora”. U: Hrvatska u izborima '90, ur. Ivan Grdešić, Mirjana Kasapović, Ivan Šiber i Nenad Zakošek. Zagreb: Naprijed, 1991, 98-130.

THOMPSON, Mark. Kovanje rata. Mediji u Srbiji, Hrvatskoj i Bosni i Hercegovini. Preveo Miodrag Pavić. Zagreb: Hrvatski helsinški odbor za ljudska prava; Građanska inicijativa za slobodu javne riječi, 1995.

VAN DALEN, Arjen. „Structural Bias in Cross-National Perspective: How Political Systems and Journalism Cultures Influence Government Dominance in the News". The International Journal of Press/Politics 17 (2012), br. 1: 32-55.

VOLTMER, Katrin. „The Mass Media and the Dynamics of Political Communication in Processes of Democratization: An Introduction". U: Mass Media and Political Communication in New Democracies, ur. Katrin Voltmer. London; New York: Routledge, 2004, 1-16.

WEAVER, David; MCCOMBS, Maxwell; SHAW, Donald L. „Agenda-Setting Research: Issues, Attributes, and Influences". U: Handbook of Political Communication Research, ur. Lynda Lee Kaid. Mahwah: Lawrence Erlbaum, 2004, 257-283.

WU, H. Denis; SYLVESTER, Judith; HAMILTON, John Maxwell. „Newspaper Provides Balance in Palestinian/Israeli Reports". Newspaper Research Journal 23 (2002), br. 2-3: 6-17.

ZAKOŠEK, Nenad. „Izborna geografija hrvatskih izbora 1990.” U: Hrvatska u izborima '90, ur. Ivan Grdešić, Mirjana Kasapović, Ivan Šiber i Nenad Zakošek. Zagreb: Naprijed, 1991, 217-219. 


\section{SUMMARY}

\section{Media Bias? The 1990 Croatian Elections in the Croatian Press}

The paper deals with the coverage of the election campaign of the first free parliamentary elections in Croatia in the Croatian press. The aim is to establish whether media bias existed in the coverage of the election campaign of the first round of the parliamentary elections in 1990. It analyses how the dailies Vjesnik [Herald] and Večernji list [Evening Paper] and weeklies Danas [Today] and ST covered the political parties and coalitions in the examined period. Three subdivisions of media bias are defined: gatekeeping bias, which is a tendency of the media to give a disproportionate amount of space to the election favourites; content bias, which exists if the relevant options are not given an equal amount of space; and statement bias, which exists if some relevant parties are portrayed in a more favourable way than the others. The first aim of the research is to demonstrate whether media bias existed in the coverage of the election campaign, and the second to determine whether media pluralism existed after almost half a century of a one-party socialist system. Quantitative content analysis is used to analyse a total of 1,185 articles included in the research. It is shown that media bias existed in all analysed media, but the favoured and marginalised parties were different.

Key words: media bias; 1990 Croatian elections; transition; media pluralism; HDZ, SKH-SDP, KNS 